\title{
Mineralogical and geochemical investigation of megaspherulites from Argentina, Germany, and the USA
}

\author{
Christoph Breitkreuz $^{1}$ (D) $\cdot$ Jens Götze ${ }^{2} \cdot$ Alexandra Weißmantel $^{2}$
}

Received: 22 July 2020 / Accepted: 5 January 2021 / Published online: 19 February 2021

(C) The Author(s) 2021

\begin{abstract}
Textures and whole-rock chemistry, as well as mineral composition, were analyzed in megaspherulites (high-temperature crystallization domains [HTCDs]) that formed in different geographical and geotectonic contexts and during different geological periods (Silver Cliff, CO, USA-Paleogene; El Quevar, Argentina-Miocene; Meissen Volcanic Complex, Germany—Late Carboniferous). All of these megaspherulites have formed exclusively in rhyolitic lava, and their mineral composition is dominated by $\mathrm{K}$-feldspar (sanidine) and $\mathrm{SiO}_{2}$ phases (quartz, cristobalite, tridymite). All megaspherulites represent composite HTCDs, comprising three zones: inner domain (ID), outer domain (OD), and a marginal domain (MD). Early evolution of megaspherulites is characterized by either central cavities and sector- to full-sphere spherulites or dendritic quartz-sanidine domains. The latter consist of bundles of fibrils each radiating from a single point reflecting relatively high growth rates. A common feature of OD and MD of all three megaspherulite occurrences is autocyclic banding. It mainly comprises fibrous $(\leq$ $100 \mu \mathrm{m}$ length), radially oriented sanidine and quartz, which formed at a temperature close to glass transition temperature $\left(T_{\mathrm{g}}\right)$. The termination of megaspherulite growth is marked by centimeter-sized sector-sphere spherulites on the surface. Megaspherulite formation requires limited nucleation, which is probably related to the low phenocryst content of the hosting lava. Latent heat from overlying crystallizing lithoidal rhyolite maintained low undercooling conditions keeping nucleation density low and facilitating high diffusion and growth rates. Late megaspherulite growth and its termination under low diffusion conditions is controlled by cooling close to $T_{\mathrm{g}}$. Calculations based on literature data suggest that the megaspherulite growth presumably lasted less than 60 years, perhaps 30 to 40 years.
\end{abstract}

Keywords Rhyolitic lava $\cdot \mathrm{SEM} \cdot \mathrm{CL} \cdot \mathrm{XRD} \cdot \mathrm{EPMA} \cdot$ Cristobalite $\cdot$ Tridymite

\section{Introduction}

Spherulites are high-temperature crystallization domains (HTCDs; Breitkreuz 2013; Iddings 1887; Bryan 1941; Lofgren 1971a; McArthur et al. 1998; Castro et al. 2008) that may form in cooling silica-rich lava, ignimbrite, or subvolcanic bodies. Lithophysae are HTCDs that develop one or more cavities during growth. While

Editorial responsibility: K.V. Cashman

Christoph Breitkreuz

cbreit@geo.tu-freiberg.de

1 Geological Department, TU Bergakademie Freiberg, Freiberg, Germany

2 Mineralogical Department, TU Bergakademie Freiberg, Freiberg, Germany millimeter- to decimeter-sized HTCDs are abundant in silica-rich volcanic and subvolcanic rocks, megaspherulites with diameters of $1 \mathrm{~m}$ and more are scarce (Smith et al. 2001; Bustos et al. 2020). This implies that they form only under very special conditions. The main variable is the cooling rate from eruption temperatures of $800-900{ }^{\circ} \mathrm{C}$ to the glass transition temperature $\left(T_{\mathrm{g}}\right.$; Sakka and MacKenzie 1971; Giordano et al. 2008) and below. This, in turn, is controlled by melt composition, $\mathrm{H}_{2} \mathrm{O}$ content, initial temperature, thermal conductivity, thickness of the cooling body, and latent heat. A low cooling rate decreases the $T_{\mathrm{g}}$ (Gottsmann et al. 2002). The early phase of megaspherulite formation in a silica-rich lava/ignimbrite body is characterized by high growth rates and low nucleation density. Typical of the megaspherulite occurrences studied here is the scarcity or absence of small spherulites in the lava host. For the megaspherulites near Silver Cliff, CO, Smith et al. 
(2001) assumed "sparse heterogeneous nucleation, under highly non-equilibrium conditions" as the main controlling parameters.

Textures and composition are here analyzed in detail for megaspherulites that formed in different geographical and geotectonic contexts and during different geological periods (Cenozoic, Late Carboniferous). In contrast to normal HTCD, the studied megaspherulites display a distinct concentric zonation. We combine macro- and microscopic analysis, wholerock and mineral chemistry (XRF, SEM-EDX), X-ray diffraction (XRD), and cathodoluminescence (CL) to document the complex evolution of megaspherulites, and to provide the basis for a generic formation model.

\section{Previous studies on megaspherulites and geological setting of investigated samples}

\section{HTCD and megaspherulites}

Spherulites and lithophysae have been studied since the early nineteenth century (Rose 1827; see review in Breitkreuz 2013). The typically millimeter- to decimeter-sized HTCDs form in silica-rich lava, ignimbrites, and subvolcanic bodies above the glass transition temperature (Sakka and MacKenzie 1971; Giordano et al. 2008); however, growth may continue during cooling to c. $400{ }^{\circ} \mathrm{C}$ (Lofgren 1971a, b; Castro et al. 2008; Watkins et al. 2009; Clay et al. 2013). Often the crystallized domain displays a fibrous texture radiating outwards from a central nucleus; however, HTCDs with a microcrystalline texture (called spheruloid by Bryan 1941) are also abundant. A HTCD with one or more cavities formed during growth is called lithophysa (Richthofen 1860). Breitkreuz (2013) summarized arguments for a model where transient tensional stress in the melt close to the HTCD crystallization front may cause a cavity formation.

Megaspherulites with diameters up to $4.3 \mathrm{~m}$ have been reported from lava and ignimbrites in the Western US (Steens Mountains and Opal Butte in Oregon, Klondyke in Arizona, and Silver Cliff in Colorado), from Argentina and from Mexico (Stirling 1969; Smith et al. 2001; Breitkreuz 2013; Bustos et al. 2020). Ottens and Götze (2016) mentioned meter-sized megaspherulites from various localities in China. The present study describes and compares megaspherulites from three localities: (i) Silver Cliff megaspherulites (SCM; Smith et al. 2001), (ii) El Quevar megaspherulites in northwestern Argentina (EQM; Willson et al. 1999), and (iii) Meissen lava megaspherulites (MLM; Jentsch 1981). Some of the megaspherulites contain cavities and thus should be coined megalithophysae; however, the name megaspherulite is established in literature.

\section{Silver Cliff megaspherulites}

Knowledge about the spectacular megaspherulites in a pitchstone quarry north of Silver Cliff (CO) goes back to the end of the nineteenth century (Cross 1891; overview in Smith et al. 2001). The hosting Paleogene lava, 76-106 $\mathrm{m}$ thick, covering approximately $3 \mathrm{~km}^{2}$, is vertically subdivided into three zones (Siems 1968; Smith et al. 2001): (i) a lower perlitic vitrophyre, (ii) a middle rhyolitic vitrophyre, and (iii) an upper thick, flow-layered lithoidal rhyolite, with small spherulites at its base. The megaspherulites occur in the upper portion of the middle zone, isolated or in clusters (Fig. 1). Thirty-seven (mega-)spherulites of 0.2 to $4.3 \mathrm{~m}$ have been observed/ collected by Smith et al. (2001) in the 58-m-wide Black Obsidian Quarry.

Smith et al. (2001) provided macroscopic and microscopic description, XRD, microprobe analysis of feldspar and garnet, CL, and whole-rock geochemistry. They distinguished, from interior to exterior, between a compound megaspherulite (zone 1), a sanidine-quartz rim (zone 2), and an alteration layer. Zone 1 displays variations in texture from one megaspherulite to the other such as larger growth cones with cone-in-cone texture. Smith et al. (2001) also reported mammilla textures on the outer surface of zone 1. As the dominant texture of zone 1, they described fibril bundles of sanidine and quartz arranged in dendritic aggregates, surrounded by a fine-grained groundmass of sanidine and quartz. Zone 2 comprises a friable, fine-grained rind $\leq 13 \mathrm{~mm}$ thick. The "hydrothermal" alteration layer is composed of fine-grained quartz, sanidine, mordenite, and montmorillonite (Smith et al. 2001). The megaspherulite and enclosing pitchstone contain a small amount (2-3 vol\%) of albitic plagioclase and biotite phenocrysts. Smith et al. (2001) also reported on "secondary" Mn-garnet confined to the megaspherulites. Whole-rock analyses indicate $\mathrm{K}$ enrichment and $\mathrm{Na}$ depletion in the megaspherulite compared to the hosting vitrophyre, suggesting element diffusion in both directions during megaspherulite growth. Smith et al. (2001) estimated that growth of the large megaspherulites $(\leq 4.27 \mathrm{~m})$ lasted about 66 years.

One of us (CB) visited the quarry north of Silver Cliff in 2014, collecting in situ samples from a megaspherulite (Fig. 1b), and loose blocks in order to cover the range of SCM textures and composition.

\section{El Quevar megaspherulites}

On the southern flanks of the El Quevar-Azufrero stratovolcano complex in northwest Argentina, the perlitic rhyolitic Quirón lava dome formed during the Miocene (Willson et al. 1999). For this dome, Laurenzi et al. (2007) published $\mathrm{a}^{40} \mathrm{Ar} /{ }^{39} \mathrm{Ar}$ age of $8.77 \pm 0.09 \mathrm{Ma}$. The EQMs (Fig. 2) occur 


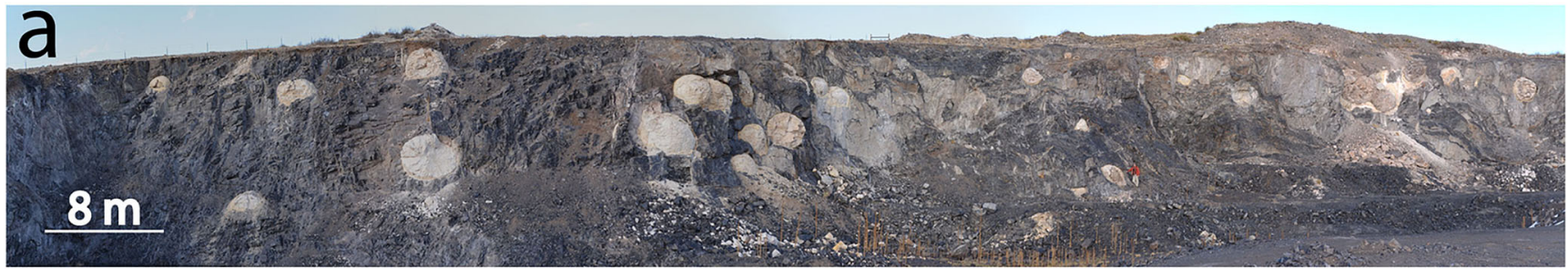

Fig. 1 Silver Cliff a quarry overview; for scale, see person with red anorak in the right half of the picture; $\mathbf{b}$ close-up view of a megaspherulite sampled in situ (samples 13/3/14a, b, c, d)

in the upper part of a $>30$-m-thick, fractured green, aphyric perlitic pitchstone, which is covered by $<3 \mathrm{~m}$ of white, relatively devitrified, rhyolite with a flow banded structure (Willson et al. 1999). The pitchstone contains small phenocrysts of biotite ( $2 \mathrm{vol} \%$ ), plagioclase feldspar ( $2 \mathrm{vol} \%)$, and quartz (1 vol\%). The ellipsoid lithophysae $(10-70 \mathrm{~cm})$ mainly consist of quartz and plagioclase. Willson et al. (1999) also mentioned chevron-shaped cavities in the outer marginal zone. The focus of the contribution by Willson et al. (1999) was the FTIR of lithophysae, hosting perlitic pitchstone and obsidian (Apache's tears). Next to silicate minerals in the HTCD (feldspar, quartz, cristobalite, biotite), the authors detected the presence of $\mathrm{H}_{2} \mathrm{O}$ and $\mathrm{OH}^{-}$in both the megaspherulites and the perlitic host.

One of us (CB) sampled fragments of megaspherulites and of decimeter-sized spherulites at the Quirón quarry in 2007.

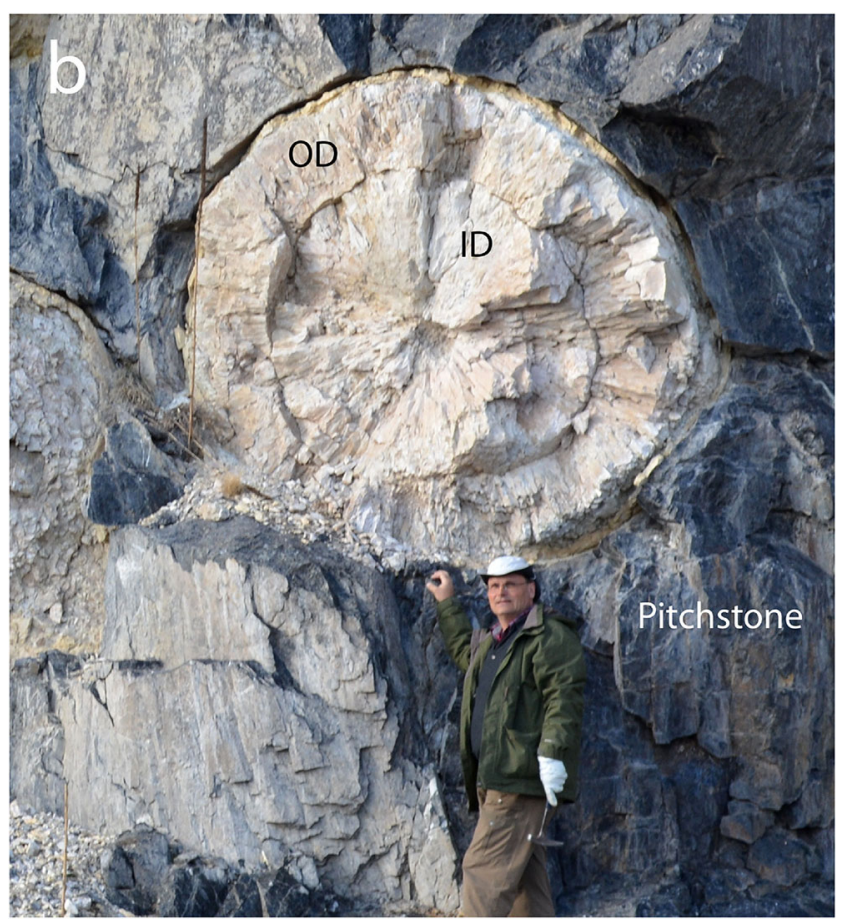

\section{Meissen lava megaspherulites}

The Late Carboniferous Meissen lava crops out west of the town of Meissen (Saxony, Germany). It forms part of the 10-km-wide Meissen Volcanic Complex, which, apart from the voluminous rhyolitic lava, comprises pyroclastic deposits and dykes (Hoffmann et al. 2013). The complex which yielded $\mathrm{U} / \mathrm{Pb}$ ages of $302.9 \pm$ 2.5 Ma overlies a 330-Ma monzonite with an erosional unconformity (Hoffmann et al. 2013). The Meissen lava consists mainly of flow-foliated, phenocryst-poor lithoidal rhyolite. It contains a number of rounded to elongate domains of pitchstone ( $\leq 3 \mathrm{~km}$ in length) which host the MLMs. Rhyolite and pitchstone contain c. 5 vol\% of phenocrysts (quartz, feldspar, biotite; Lange and Heide 1996).

The pitchstone has been quarried since 1868 as a raw material for the glass and ceramic industry because of its high $\mathrm{SiO}_{2}(71.6 \mathrm{wt} \%)$ and low $\mathrm{Fe}_{2} \mathrm{O}_{3}$ contents $(1.1 \mathrm{wt} \%$; Lange and Heide 1996). The pitchstone has minor domains which contain centimeter-sized spherulites as well as meter-sized crystallization domains (Jentsch 1981). The latter comprise two types:

i) $\leq 7-\mathrm{m}$ ellipsoid, concentrically zoned domains with a perlitic texture, crystallized to quartz, K-feldspar, and zeolite, and

ii) $\leq 1$-m concentrically zoned HTCD comprising mainly quartz and $\mathrm{K}$-feldspar.

The former domains, called "Wilde Eier" ("wild eggs") by the ancient miners, crystallized from perlitic glass, presumably during the final phase of cooling or during later hydrothermal activity. From the latter, the Meissen lava megaspherulites (MLMs) considered here, a $90-\mathrm{cm}$ megaspherulite has been recovered during a construction work at the locality of Hoher Geiger in 2016 (Fig. 3). Smaller MLMs, complete or fragments, have been found earlier. To date, no systematic description of the MLMs has been published.

Fig. 1 (continued) 


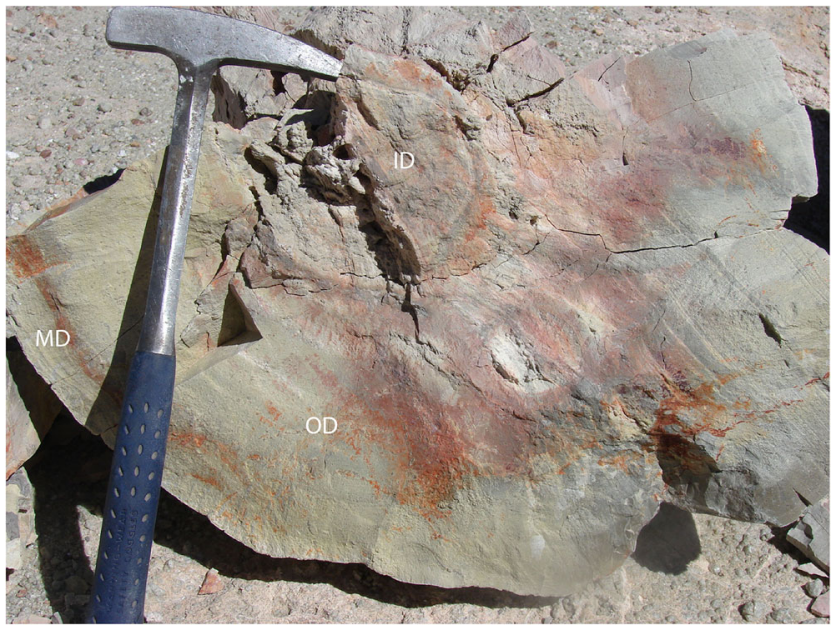

Fig. 2 Broken-open megaspherulite from El Quevar (Argentina)

\section{Methods}

The megaspherulite samples were visually described and documented, and selected pieces were partially ground for further analysis. Polished fragments of the megaspherulites were examined regarding their microstructural features under a ZEISS stereo microscope. Polished rock slabs and thin sections (30 $\mu \mathrm{m}$ thick) have been prepared for photographic documentation and for investigation with polarizing microscopy, cathodoluminescence (CL), and scanning electron microscopy (SEM). Representative aliquots of these samples were further prepared according to the analytical requirements of mineral analysis by X-ray diffraction (XRD) and chemical analysis of major and minor elements by $\mathrm{X}$-ray fluorescence (XRF), respectively.

Conventional polarizing microscopy was done by using a Zeiss Axio Imager A1m microscope for petrographic characterization of the rock fabric, texture, phase composition, and microtextural features. These investigations were complemented by SEM measurements (SE, BSE, EDX) on carbon-coated thin sections and polished sample pieces using a JEOL JSM-7001F (20 kV, $2.64 \mathrm{nA})$. The EDX system Quantax Dual XFlash 5010/Nano Dual XFlash 5030 (BRUKER) with the software MLA-Suite 3.1 (JKTech-FEI) was used for local chemical analysis of individual mineral grains. The SEM-EDX results (Electronic Supplement Table S1) were used for the identification of mineral phases, the calculation of the chemical composition of individual crystals, and the detection of heterogeneities within minerals (e.g., zoning).

CL measurements were made on carbon-coated, polished thin sections using a "hot cathode" CL microscope HC1-LM (Neuser et al. 1995). The system was operated at $14 \mathrm{kV}$ accelerating voltage and a current of $0.2 \mathrm{~mA}$ (current density of about $10 \mu \mathrm{A} / \mathrm{mm}^{2}$ ). Luminescence images were captured "online" during CL operations using a Peltier-cooled digital video camera (OLYMPUS DP72). CL spectra in the wavelength range 380 to $900 \mathrm{~nm}$ were recorded with an Acton Research

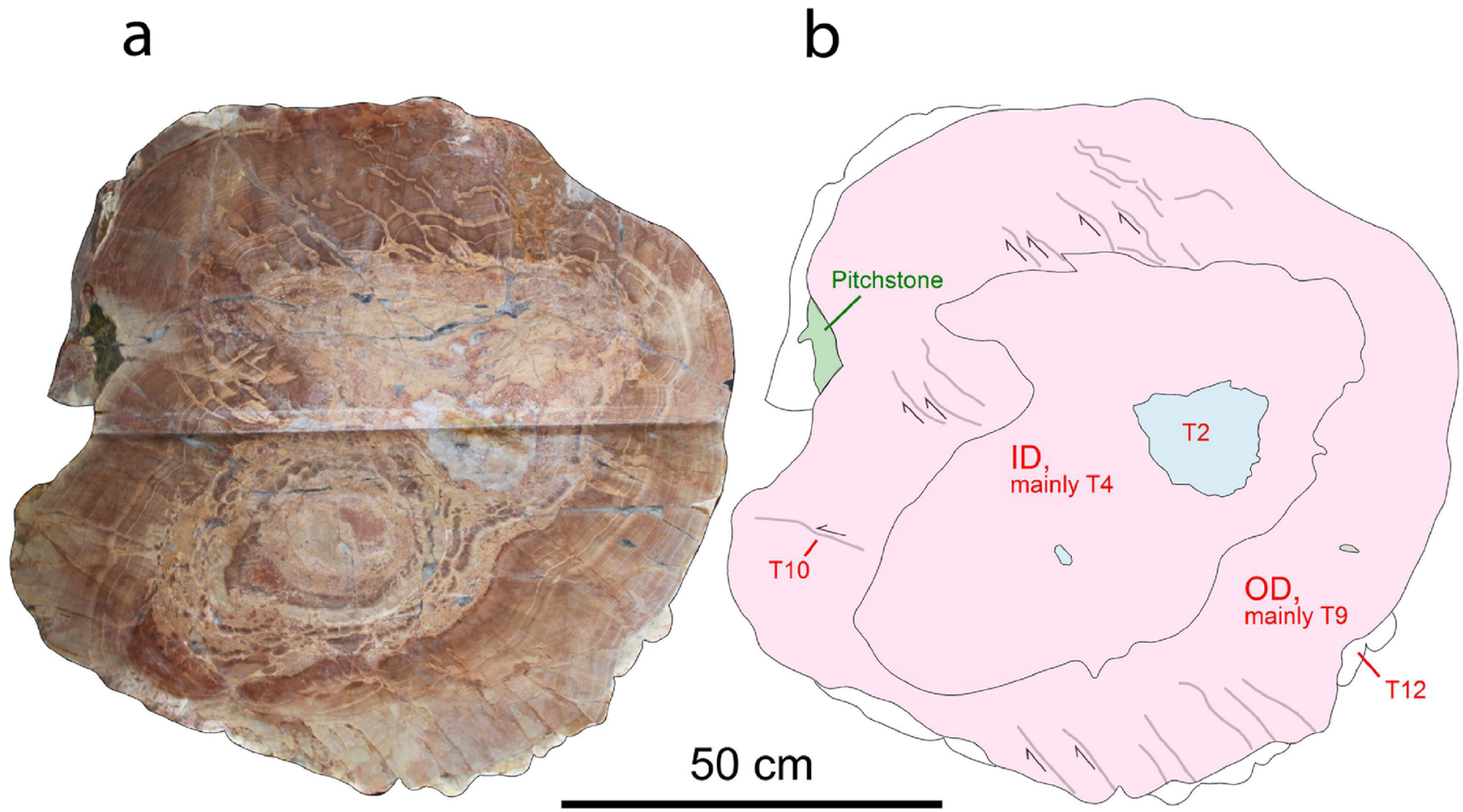

Fig. 3 Photograph of the split-open Meissen lava megaspherulite (MLM): a photo and $\mathbf{b}$ redrawn sketch of a with sketched-in major domains 
SP-2356 digital triple-grating spectrograph with a Princeton Spec-10 CCD detector that was attached to the CL microscope by a silica-glass fiber guide. CL spectra were measured under standardized conditions (wavelength calibration by a $\mathrm{Hg}$ halogen lamp, spot width $30 \mu \mathrm{m}$, measuring time $2 \mathrm{~s}$ ).

The geochemistry and mineral composition of the megaspherulites as well as of the host rocks were further characterized by a combination of X-ray fluorescence (XRF) and $\mathrm{X}$-ray diffraction (XRD) analyses on a selected sample material (grain size $<20 \mu \mathrm{m}$ ). For XRF measurements, the powdered sample $(<63 \mu \mathrm{m})$ was calcinated, mixed, and homogenized with Li borate, and a fusion disk was produced. The disks were analyzed by using a PANalytical Axios Minerals spectrometer and the WROXI software. The chemical composition of megaspherulites and their host material (pitchstone/obsidian) are given in Table 2.

For the qualitative and quantitative phase analysis, an $\mathrm{X}$ ray diffractometer (URD 6, Seifert/Freiberger Präzisionsmechanik) with Co $\mathrm{K} \alpha$ radiation in the range 5$80^{\circ}(2 \theta)$ had been employed. Analytical conditions included a detector slit of $0.25 \mathrm{~mm}, 0.03^{\circ}$ step width, and $5 \mathrm{~s}$ measuring time. Data were evaluated qualitatively with the Analyze RayfleX v.2.352 software and quantitatively with Rietveld refinement using Autoquan v.2.7.00 according to Taut et al.
(1998). The quantitative mineral composition of megaspherulite samples is presented in Table 3.

\section{Results}

\section{General structure and composition of the three megaspherulite types}

The megaspherulites have a general common structure, comprising an inner domain (ID), an outer domain (OD), and a marginal domain (MD). For all examined megaspherulites, we describe the dominant microtextures ( $T 1$ to $T 15$; Table 1) and their in situ mineral composition (Electronic Supplement Fig. S6 and Table S1). Some microtextures, such as flow foliation (T1) or sector-sphere spherulites on the outer surface (T12), are common to megaspherulites of all three localities. In SCM and MLM, radiate to obliquely curved crevasses (T10) crosscut MD and OD, filled with spherulitic domains (Fig. 5). Other textures like the dendritic quartz/feldspar aggregates $(\boldsymbol{T} \boldsymbol{6})$ and authigenic garnet $(\boldsymbol{T} \boldsymbol{8})$ in $\mathrm{SCM}$, or coneshaped dimples (T14) and chevron-shaped cavities (T15) in EQM are unique to one megaspherulite locality.

Table 1 Textures observed on rock slabs and in thin sections of Silver Cliff (SCM), El Quevar (EQM), and Meissen lava megaspherulite (MLM); ID inner domain, $O D$ outer domain, $M D$ margin domain

\begin{tabular}{|c|c|c|c|c|}
\hline Texture & Description & SCM & EQM & MLM \\
\hline $\mathrm{T} 1$ & Flow foliation, marked by aligned microliths & $\mathrm{ID}, \mathrm{OD}, \mathrm{MD}$ & $\mathrm{ID}, \mathrm{OD}, \mathrm{MD}$ & $\mathrm{ID}, \mathrm{OD}, \mathrm{MD}$ \\
\hline $\mathrm{T} 2$ & Irregular decimeter-sized cavities, in MLM filled with Qtz & & ID & ID \\
\hline $\mathrm{T} 3$ & Microcrystalline, no orientation & ID, OD & & \\
\hline $\mathrm{T} 4$ & $\begin{array}{l}\text { Sector- to full-sphere spherulites with concentric internal zonation; spherulites } \\
\text { are scale-like arranged along the growth direction of the megaspherulite }\end{array}$ & & ID & ID \\
\hline $\mathrm{T} 5$ & $\begin{array}{l}\text { Crystal aggregates, in places in the form of small spherulites, irregularly distributed } \\
\text { in a fine groundmass (T3) }\end{array}$ & & & ID \\
\hline T6 & $\begin{array}{l}\text { Centimeter-sized, dendritic Qtz, Fsp aggregates, oriented parallel to the growth } \\
\text { direction of the megaspherulite; dendritic aggregates comprise fibrous crystals } \\
\text { arranged in a common growth and optical orientation }\end{array}$ & ID, OD & & \\
\hline $\mathrm{T} 7$ & $\begin{array}{l}1-2 \mathrm{~cm} \text {-sized, irregular to triangular domains with a microcrystalline, radiate fibrous } \\
\text { texture }\end{array}$ & OD & & \\
\hline $\mathrm{T} 8$ & Poikiloblastic and euhedral aggregates of Mn-garnet ( $\leq 0.6 \mathrm{~mm}$ size $)$ & ID, OD & & \\
\hline T9 & $\begin{array}{l}\text { Autocyclic growth banding }(0.3-0.6 \mathrm{~mm} \text { wide }) \text {, fibrous crystals of Qtz and K-Fsp, } \\
\text { oriented perpendicular to the growth banding; crystals are grouped to irregular, } \\
0.2 \text {-mm-sized blotches, with common internal optical orientation }\end{array}$ & MD & MD & $\mathrm{OD}, \mathrm{MD}$ \\
\hline $\mathrm{T} 10$ & $\begin{array}{l}\text { Straight to curved crevasses, perpendicularly or obliquely oriented to the outer surface } \\
\text { of the megaspherulite; up to } 10 \mathrm{~mm} \text { wide; filled with sector- to full-sphere, fibrous spherulites and } \\
\text { lithophysae, randomly oriented in a fine-crystalline groundmass }\end{array}$ & $\mathrm{OD}, \mathrm{MD}$ & & $\mathrm{OD}, \mathrm{MD}$ \\
\hline T11 & Angular breccia, matrix between fragments is finely crystallized Fsp & ID & & ID, MD \\
\hline $\mathrm{T} 12$ & $\begin{array}{l}\text { Centimeter-sized sector-sphere, fibrous spherulites located on the outer ("mammillated") } \\
\text { skin of the megaspherulite; in places, thin, sickle-shaped domains have been observed } \\
\text { inside oriented perpendicular to the spherulite fibers }\end{array}$ & MD & $\mathrm{MD}$ & MD \\
\hline $\mathrm{T} 13$ & $\begin{array}{l}\text { Centimeter-sized, cone-shaped dimples with radiate grooves; some dimples are almost completely } \\
\text { filled with crystal fibers oriented perpendicular to the outer megaspherulite skin }\end{array}$ & & $\mathrm{MD}$ & \\
\hline $\mathrm{T} 14$ & $\begin{array}{l}\text { Domains of fibrous Fsp, Qtz crystals with dendritic smectite interlayers; the parallel fibers and their } \\
\text { optical orientation are arranged perpendicular to the outer skin of the megaspherulite }\end{array}$ & OD & $\mathrm{MD}$ & \\
\hline T15 & $\begin{array}{l}\text { Chevron-shaped cavities (concave side out), in places filled with agate; T13 is located below T12 } \\
\text { domains, in places }\end{array}$ & & $\mathrm{MD}$ & \\
\hline
\end{tabular}


We also document the whole-rock composition (Table 2) and mineral phase proportions (Table 3) as well as characteristic textures on polished rock slabs and thin sections which are depicted in Figs. 4, 5, and 8. In situ compositions of key minerals are listed in Table S1, and further microphotographs and cathodoluminescence images are documented in Figs. S1 to S5.

\section{Silver Cliff, CO (USA)}

\section{Whole-rock mineralogy and chemistry}

The megaspherulites at Silver Cliff, with diameters up to $4.3 \mathrm{~m}$, occur in a weakly porphyritic rhyolitic vitrophyre (pitchstone), and they are commonly mantled by a c. 3-cm-thick clay-zeolite rim consisting of a mixture of mordenite and dioctahedral smectite (Fig. 1b and Table 3; Smith et al. 2001). The host rock (pitchstone) is compact and has a black to greenish-black holohyaline matrix with few, millimeter-sized phenocrysts of Na-rich plagioclase and biotite; the same phenocryst population is observed inside SCM. The pitchstone reveals LOI between 5.3 and $5.7 \mathrm{wt} \%$, and this is interpreted as the $\mathrm{H}_{2} \mathrm{O}$ content (Table 2). The different parts of SCM and its pitchstone host are of rhyolitic composition (Table 2 and Fig. 6). The megaspherulite samples reveal remarkably high concentrations of $\mathrm{K}_{2} \mathrm{O}$ and a low $\mathrm{Na}_{2} \mathrm{O}$ content compared to the host (Fig. $7 \mathrm{~b}$ and Table 2). The claymordenite alteration zone is enriched in $\mathrm{CaO}, \mathrm{MgO}, \mathrm{Al}_{2} \mathrm{O}_{3}$, and $\mathrm{Fe}_{2} \mathrm{O}_{3}$. Similar results were reported by Smith et al. (2001).

The mineral phase composition of SCM (Table 3 ) is dominated by $\mathrm{K}$-feldspar (sanidine) and quartz, with moderate contents of Ca-poor plagioclase (oligoclase-andesine). The biotite content is low, and smectite represents a first alteration product of restitic glass. The fine-grained spherulitic matrix is mostly composed of sanidine and quartz intergrowths, whereas plagioclase and sparse biotite occur as phenocrysts. Accessory minerals are magnetite, ilmenite, and zircon. Noteworthy is the presence of up to 0.6-mm-large garnet crystals (Fe-rich spessartine; Fig. 8) in ID and OD, already reported by Smith et al. (2001), as well as fluorite in fractures and pores of the outer domain (Fig. S1h).

\section{Microtexture and in situ mineral composition}

The inner domain (ID) of the megaspherulites from Silver Cliff is dominated by a matrix of fine-grained quartz-Kfeldspar (sanidine) intergrown with some areas of microspherulites in the innermost part. Apart from flow

Table 2 Chemical composition (XRF, in wt\%) of Silver Cliff megaspherulite (SCM), El Quevar megaspherulite (EQM), and Meissen lava megaspherulite (MLM), and of hosting pitchstone/obsidian $(\mathrm{SrO}<$

$0.01, \mathrm{BaO}<0.01, \mathrm{ZrO}_{2}<0.03, \mathrm{P}_{2} \mathrm{O}_{5}<0.06$ : near or below detection limit)

\begin{tabular}{|c|c|c|c|c|c|c|c|c|c|c|c|c|}
\hline & Sample & $\begin{array}{l}\mathrm{SiO}_{2} \\
(\mathrm{wt} \%)\end{array}$ & $\begin{array}{l}\mathrm{TiO}_{2} \\
(\mathrm{wt} \%)\end{array}$ & $\begin{array}{l}\mathrm{Al}_{2} \mathrm{O}_{3} \\
(\mathrm{wt} \%)\end{array}$ & $\begin{array}{l}\mathrm{Fe}_{2} \mathrm{O}_{3} \\
(\mathrm{wt} \%)\end{array}$ & $\begin{array}{l}\mathrm{Mn}_{3} \mathrm{O}_{4} \\
(\mathrm{wt} \%)\end{array}$ & $\begin{array}{l}\mathrm{MgO} \\
(\mathrm{wt} \%)\end{array}$ & $\begin{array}{l}\mathrm{CaO} \\
(\mathrm{wt} \%)\end{array}$ & $\begin{array}{l}\mathrm{Na}_{2} \mathrm{O} \\
(\mathrm{wt} \%)\end{array}$ & $\begin{array}{l}\mathrm{K}_{2} \mathrm{O} \\
(\mathrm{wt} \%)\end{array}$ & $\begin{array}{l}\text { LOI } \\
(\mathrm{wt} \%)\end{array}$ & $\begin{array}{l}\text { Total } \\
\text { (wt } \%)\end{array}$ \\
\hline \multicolumn{13}{|l|}{ SCM } \\
\hline \multirow[t]{2}{*}{ ID } & $13 / 3 / 14 \mathrm{aI}$ & 75.32 & 0.06 & 12.92 & 0.59 & 0.15 & 0.13 & 0.28 & 2.45 & 6.07 & 1.53 & 99.55 \\
\hline & 13/3/14aII & 75.77 & 0.06 & 12.74 & 0.58 & 0.14 & 0.13 & 0.28 & 2.65 & 5.78 & 1.50 & 99.67 \\
\hline \multirow[t]{2}{*}{ OD } & 13/3/14bI & 74.55 & 0.06 & 13.52 & 0.51 & 0.12 & 0.06 & 0.35 & 3.25 & 5.99 & 1.33 & 99.63 \\
\hline & 13/3/14bII & 68.95 & 0.06 & 15.17 & 0.55 & 0.09 & 0.14 & 0.67 & 2.77 & 7.84 & 1.39 & 99.66 \\
\hline Clay-zeolite & $13 / 3 / 14 c$ & 66.05 & 0.07 & 14.80 & 1.04 & $<0.03$ & 0.23 & 3.04 & 2.10 & 1.29 & 10.84 & 99.75 \\
\hline \multirow[t]{4}{*}{ Pitchstone } & 13/3/14dI & 71.67 & 0.06 & 12.93 & 0.60 & 0.20 & 0.07 & 0.55 & 4.24 & 3.35 & 5.69 & 99.37 \\
\hline & 13/3/14dII & 71.63 & 0.07 & 13.01 & 0.66 & 0.22 & 0.07 & 0.65 & 4.33 & 3.39 & 5.57 & 99.63 \\
\hline & 13/3/14eI & 71.75 & 0.06 & 12.78 & 0.58 & 0.23 & $<0.05$ & 0.51 & 3.84 & 3.93 & 5.40 & 99.10 \\
\hline & 13/3/14iI & 71.55 & 0.06 & 12.88 & 0.60 & 0.20 & 0.05 & 0.52 & 3.80 & 4.20 & 5.27 & 99.13 \\
\hline \multicolumn{13}{|l|}{ EQM } \\
\hline \multirow[t]{2}{*}{ ID } & $5 / 11 / 07-3 e$ & 77.04 & 0.08 & 11.89 & 0.73 & $<0.03$ & 0.13 & 0.36 & 3.14 & 3.51 & 2.41 & 99.80 \\
\hline & $5 / 11 / 07-3 f$ & 78.45 & 0.08 & 11.68 & 0.55 & $<0.03$ & 0.09 & 0.38 & 2.89 & 3.53 & 1.23 & 99.11 \\
\hline \multirow[t]{3}{*}{ OD } & $5 / 11 / 07-3 c$ & 76.02 & 0.09 & 12.54 & 0.76 & $<0.03$ & 0.18 & 0.46 & 2.87 & 4.21 & 1.72 & 99.12 \\
\hline & 5/11/07-3dII & 80.28 & 0.09 & 10.62 & 0.56 & $<0.03$ & 0.12 & 0.36 & 2.43 & 3.60 & 1.32 & 99.64 \\
\hline & $5 / 11 / 07-3 \mathrm{~h}$ & 79.67 & 0.08 & 10.52 & 0.71 & $<0.03$ & 0.13 & 0.37 & 2.37 & 3.86 & 1.80 & 99.74 \\
\hline $\mathrm{MD}$ & 5/11/07-3dI & 73.98 & 0.09 & 13.49 & 1.10 & $<0.03$ & 0.21 & 0.58 & 3.27 & 3.86 & 2.19 & 99.21 \\
\hline Pitchstone & $5 / 11 / 07-3 b$ & 71.87 & 0.11 & 13.86 & 0.83 & 0.07 & 0.16 & 0.48 & 2.96 & 4.94 & 3.64 & 99.15 \\
\hline Obsidian & 5/11/07-3a & 74.15 & 0.11 & 14.15 & 0.87 & 0.08 & 0.29 & 0.43 & 3.65 & 4.43 & 0.78 & 99.21 \\
\hline \multicolumn{13}{|l|}{ MLM } \\
\hline \multirow[t]{4}{*}{ ID } & TT-11-1II & 78.85 & 0.08 & 10.54 & 0.27 & bdl & $<0.05$ & 0.07 & 0.83 & 7.64 & 0.80 & 99.12 \\
\hline & TT-11-3I & 80.20 & 0.08 & 10.18 & 0.32 & & $<0.05$ & 0.07 & 0.69 & 7.44 & 0.97 & 100.01 \\
\hline & TT-11-14I & 80.04 & 0.08 & 10.20 & 0.25 & & $<0.05$ & 0.06 & 0.75 & 7.42 & 0.70 & 99.52 \\
\hline & TT-11-14II & 80.86 & 0.07 & 9.84 & 0.27 & & $<0.05$ & 0.06 & 0.83 & 7.00 & 0.71 & 99.70 \\
\hline \multirow[t]{4}{*}{ OD } & TT-11-1I & 79.85 & 0.08 & 10.24 & 0.27 & & $<0.05$ & 0.10 & 0.93 & 7.11 & 0.84 & 99.46 \\
\hline & TT-11-2I & 78.12 & 0.08 & 10.83 & 0.31 & & $<0.05$ & 0.11 & 0.91 & 7.53 & 1.71 & 99.66 \\
\hline & TT-11-3II & 80.04 & 0.08 & 10.20 & 0.25 & & $<0.05$ & 0.06 & 0.75 & 7.42 & 0.84 & 99.55 \\
\hline & TT-11-3III & 80.86 & 0.07 & 9.84 & 0.27 & & $<0.05$ & 0.06 & 0.83 & 7.00 & 1.19 & 99.62 \\
\hline Pitchstone & TT-11-2II & 78.69 & 0.09 & 10.79 & 0.77 & & 0.26 & 0.15 & $<0.20$ & 6.92 & 1.96 & 99.76 \\
\hline
\end{tabular}




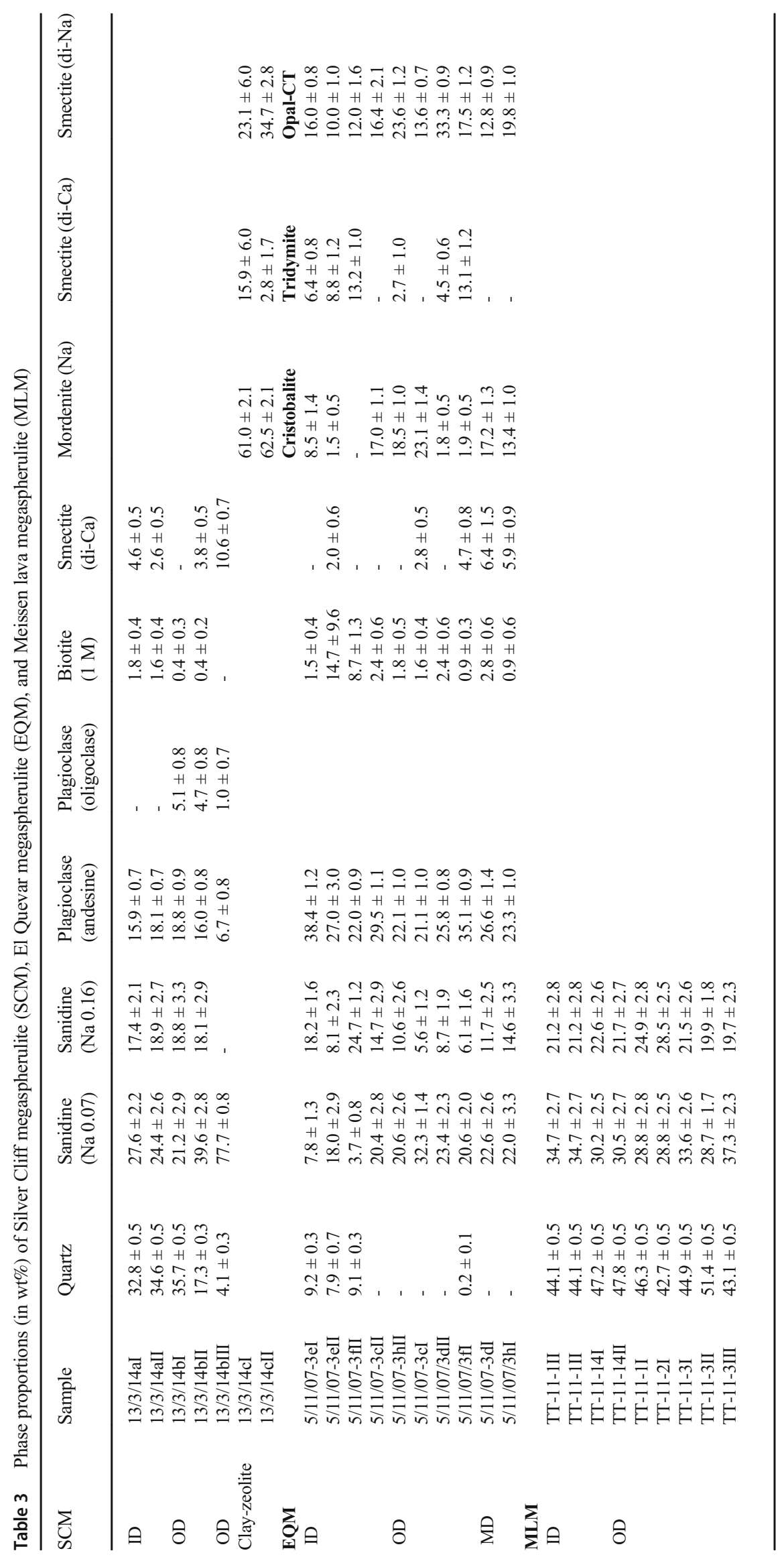




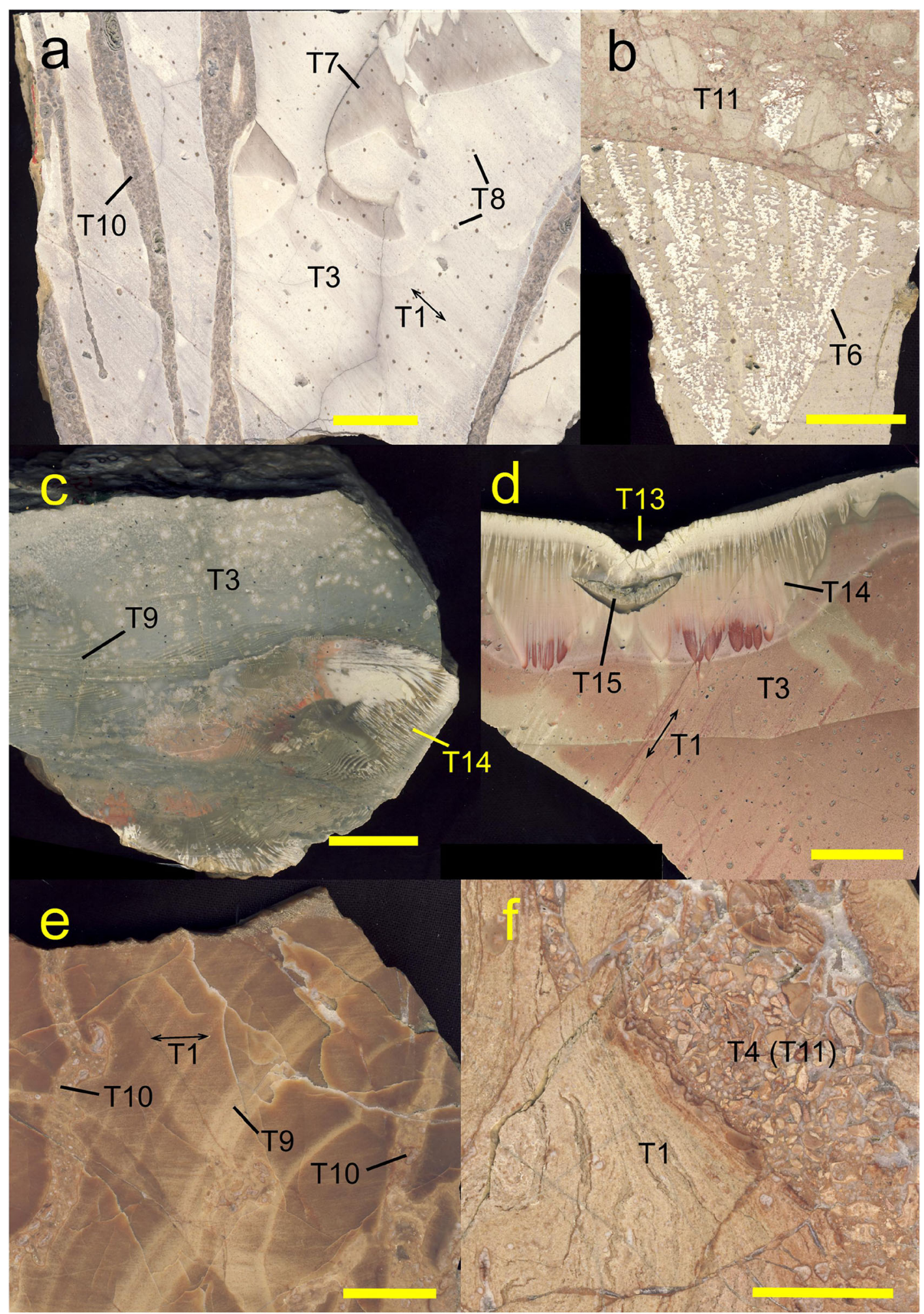

Fig. 4 Photographs of polished rock slabs of SCM, EQM, and MLM: a flow foliation (T1), crevasses (T10), and triangular domains with a radiate-fibrous texture (T7; SCM sample 13/3/14f); b lower part, coherent domain (T3) with dendritic Fsp-Qtz-aggregates (T6); upper part, brecciated (T11; SCM sample 13/3/14j); $\mathbf{c}$ flow-foliated domain (T1) with autocyclic banding (T9), lower right, domains of fibrous growth (T14; EQM sample 5/11/07/3c); d EQM sample 5/11/07/3h; lower part (OD), flow foliation (T1); upper part (MD), lateral arrangement of fibrous Fsp,
Qtz, and smectitic interlayers (T14), next to chevron-shaped, sinter-filled cavity (T15) close to dimple on outer surface (T13); e OD of MLM with flow foliation (horizontal lineation, T1), autocyclic growth banding (oblique, T9), and vertically oriented crevasses (T10) filled with spherulitic domains (sample TT-11-10); f ID of MLM (sample TT-11-14) showing flow foliation (T1) and domains with sector- to full-sphere spherulites (T4), partially brecciated (T11); yellow scale bar $=2 \mathrm{~cm}$ 


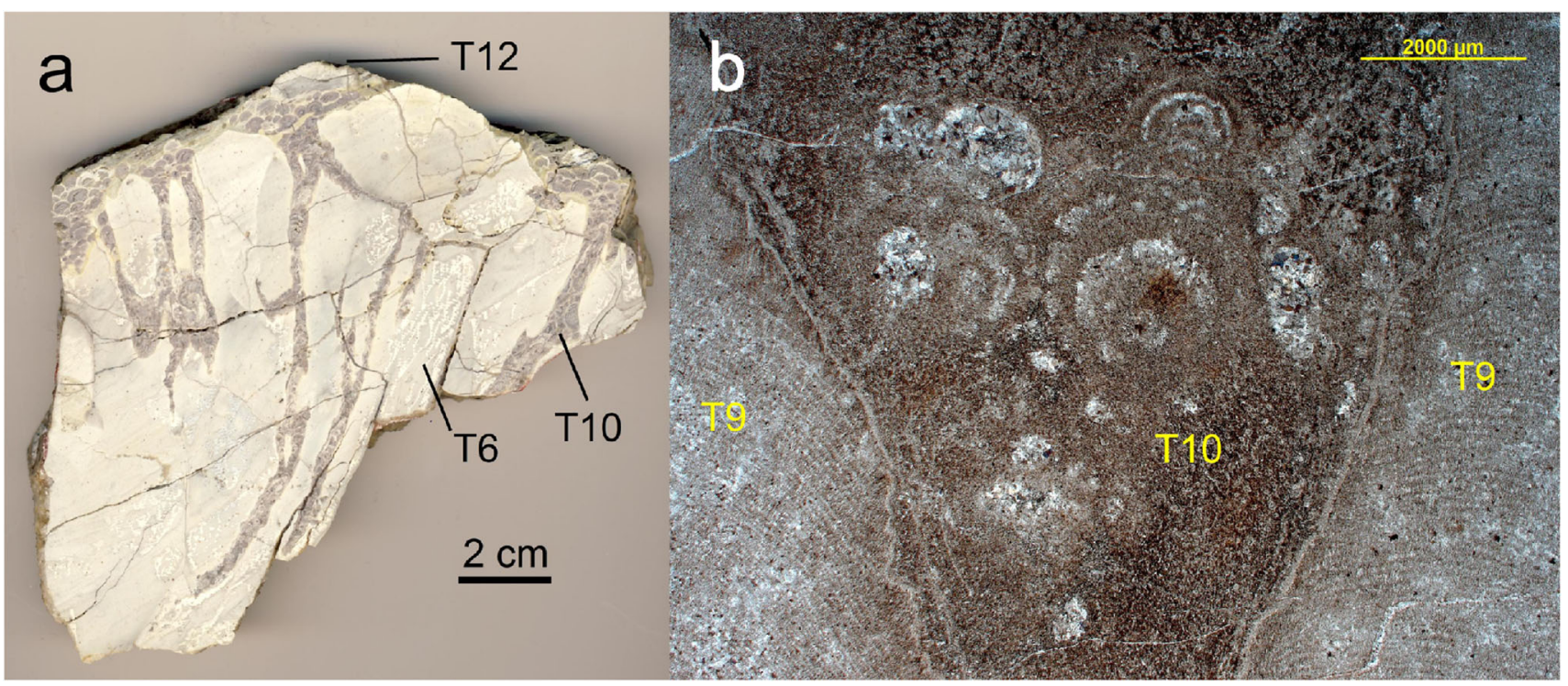

Fig. 5 Lithophysa-filled crevasses (T10): a rock slab photograph of sample 13/3/14h (SCM, OD + MD); $\mathbf{b}$ thin section, $45^{\circ}$ cross polars, sample TT11-3llb (MLM) with T10 in bent T9 (see also Fig. 12f)

foliation (T1; Table 1), fan-shaped aggregates (up to several $\mathrm{cm}$ in size) of densely packed quartz and sanidine are common (T6; Figs. 4b and 9a, b). The fan-shaped aggregates often have a thin rim of sanidine (Fig. S1a), and clay minerals have been detected in the interstices between feldspar and quartz in the fine-grained matrix, presumably an alteration product of restitic glass (Fig. S1b). XRD- (Table 3) and SEM-EDX measurements (Table S1) revealed the presence of dioctahedral smectite. In places, ID appears irregularly brecciated (T11; Figs. $4 \mathrm{~b}$ and S1c, d) and the matrix between the fragments is finely crystallized K-feldspar. Inside some of the breccia clasts, $\mathbf{T} \mathbf{6}$ dendritic aggregates formed, which are radially oriented and which have not been affected by the brecciation, suggesting that $\boldsymbol{T} \mathbf{6}$ formed after $\boldsymbol{T} 11$.

The chemical composition of matrix sanidine in SCM varies over a broad range from $\mathrm{Or}_{91} \mathrm{Ab}_{9}$ to $\mathrm{Or}_{54} \mathrm{Ab}_{46}$ without any detectable $\mathrm{Ca}$ content (Table S1 and Figure S6). Fine quartz and feldspar crystals are often grouped in irregular, $0.2-\mathrm{mm}$-sized clusters with a common internal optical orientation. Despite the small grain size, both minerals are clearly distinguishable by their different luminescence colors (Fig. 9d). Quartz mostly shows a typical dark-blue CL, whereas sanidine in most parts of the investigated samples exhibits an uncommon greenish $\mathrm{CL}$ due to activation by $\mathrm{Mn}^{2+}$ (see spectra in Fig. S2). This might be explained by the elevated concentration of $\mathrm{Na}$, which favors the structural incorporation of $\mathrm{Mn}^{2+}$ for $\mathrm{Na}^{+}$ instead of $\mathrm{K}^{+}$. In some areas, however, the common bright-blue CL of sanidine can be observed where $\mathrm{Mn}^{2+}$ is lacking (see Fig. S1d). Reddish areas in CL are related to quartz with a high defect density probably due to fast crystallization (Fig. 9b; Götze 2012).
Phenocrysts of Na-rich plagioclase within the fine-grained matrix are visible due to their bright-greenish-yellow CL (Fig. 9b). Chemical analyses by SEM-EDX yielded an oligoclase composition ranging from $\mathrm{An}_{16} \mathrm{Ab}_{77} \mathrm{Or}_{7}$ to $\mathrm{An}_{12} \mathrm{Ab}_{81} \mathrm{Or}_{7}$ (Table S1 and Figure S6). In addition, both plagioclase phenocrysts and matrix sanidine contain elevated amounts of iron (up to 0.2 and $1.2 \mathrm{wt} \% \mathrm{Fe}$, respectively). Some of this iron is incorporated as $\mathrm{Fe}^{3+}$ at the $\mathrm{Al}^{3+}$ position of the feldspar structure and detectable by CL spectroscopy (Fig. S2).

A feature of both the inner and the outer domain of the megaspherulites from Silver Cliff is the occurrence of Mnrich garnet $(\boldsymbol{T} \boldsymbol{8})$. It appears as small and relatively compact

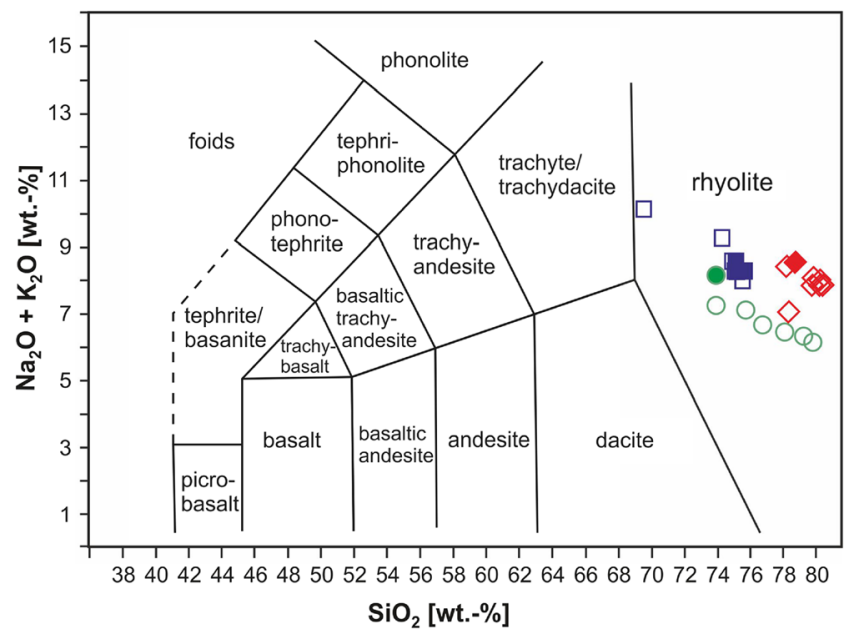

Fig. 6 Total alkali vs. silica diagram according to Le Bas et al. (1986) of the investigated megaspherulites (empty symbols) and the hosting pitchstone/obsidian (filled symbols); blue square, Silver Cliff, SCM; green circle, El Quevar, EQM; red rhomb, Triebischtal, MLM; data in Table 2 

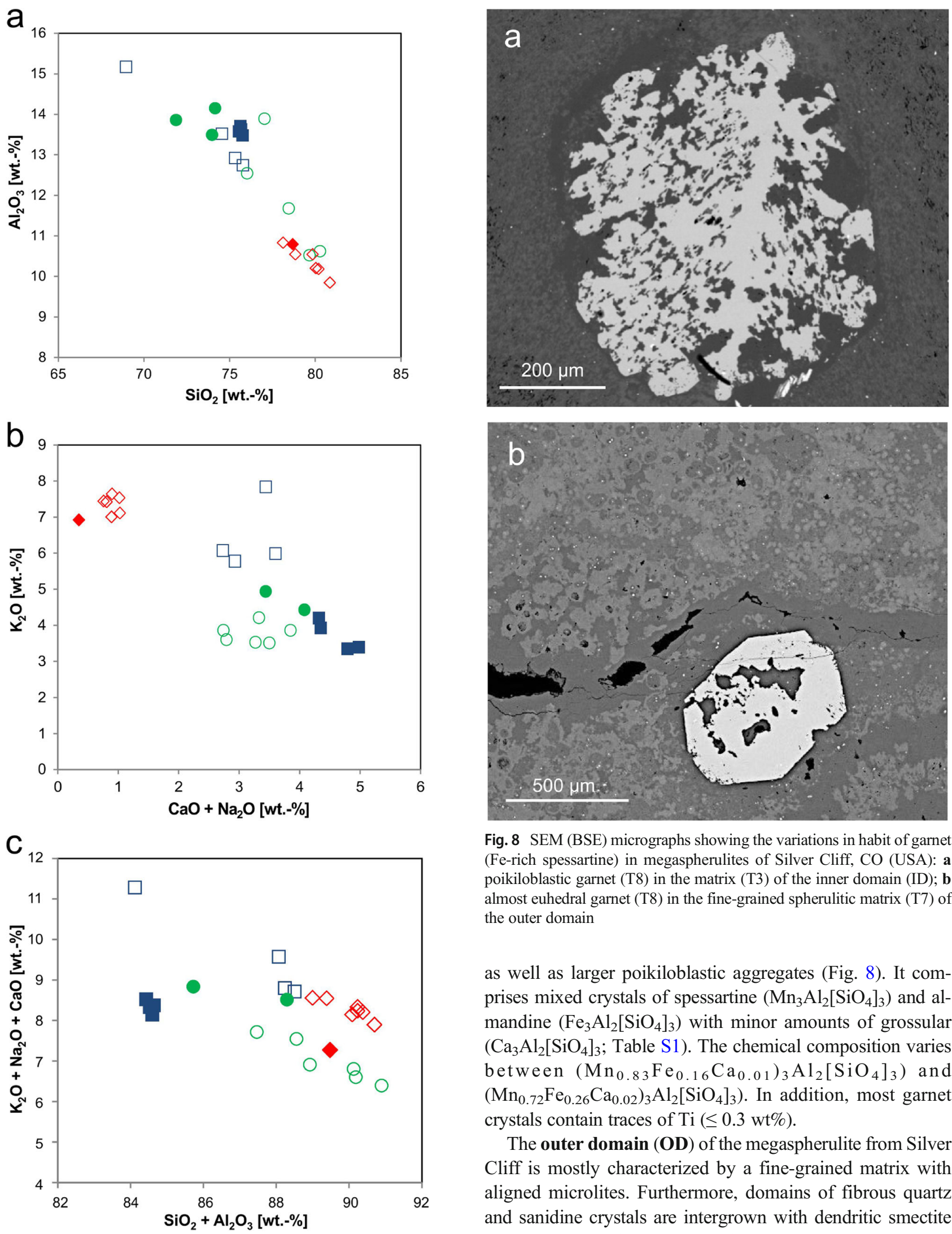

Fig. 7 a $\mathrm{Al}_{2} \mathrm{O}_{3}$ vs. $\mathrm{SiO}_{2}$ plot. b $\mathrm{K}_{2} \mathrm{O}$ vs. $\mathrm{CaO}+\mathrm{Na}_{2} \mathrm{O}$ plot. c Framework builder $\left(\mathrm{Al}_{2} \mathrm{O}_{3}+\mathrm{SiO}_{2}\right)$ vs. framework modifier $\left(\mathrm{K}_{2} \mathrm{O}+\mathrm{Na}_{2} \mathrm{O}+\mathrm{CaO}\right)$ of SCM, EQM, and MLM; for key, see Fig. 6; data in Table 2

Fig. 8 SEM (BSE) micrographs showing the variations in habit of garnet (Fe-rich spessartine) in megaspherulites of Silver Cliff, CO (USA): a poikiloblastic garnet (T8) in the matrix (T3) of the inner domain (ID); $\mathbf{b}$ almost euhedral garnet (T8) in the fine-grained spherulitic matrix (T7) of the outer domain

as well as larger poikiloblastic aggregates (Fig. 8). It comprises mixed crystals of spessartine $\left(\mathrm{Mn}_{3} \mathrm{Al}_{2}\left[\mathrm{SiO}_{4}\right]_{3}\right)$ and almandine $\left(\mathrm{Fe}_{3} \mathrm{Al}_{2}\left[\mathrm{SiO}_{4}\right]_{3}\right)$ with minor amounts of grossular $\left(\mathrm{Ca}_{3} \mathrm{Al}_{2}\left[\mathrm{SiO}_{4}\right]_{3}\right.$; Table $\left.\mathrm{S} 1\right)$. The chemical composition varies between $\left.\left(\mathrm{Mn}_{0.83} \mathrm{Fe}_{0.16} \mathrm{Ca}_{0.01}\right)_{3} \mathrm{Al}_{2}\left[\mathrm{SiO}_{4}\right]_{3}\right)$ and $\left.\left(\mathrm{Mn}_{0.72} \mathrm{Fe}_{0.26} \mathrm{Ca}_{0.02}\right)_{3} \mathrm{Al}_{2}\left[\mathrm{SiO}_{4}\right]_{3}\right)$. In addition, most garnet crystals contain traces of $\mathrm{Ti}(\leq 0.3 \mathrm{wt} \%)$.

The outer domain (OD) of the megaspherulite from Silver Cliff is mostly characterized by a fine-grained matrix with aligned microlites. Furthermore, domains of fibrous quartz and sanidine crystals are intergrown with dendritic smectite interlayers, which are arranged perpendicular to the outer megaspherulite rim (T14; Fig. 9c, d). Centimeter-sized triangular domains occur with a microcrystalline, radiate-fibrous 

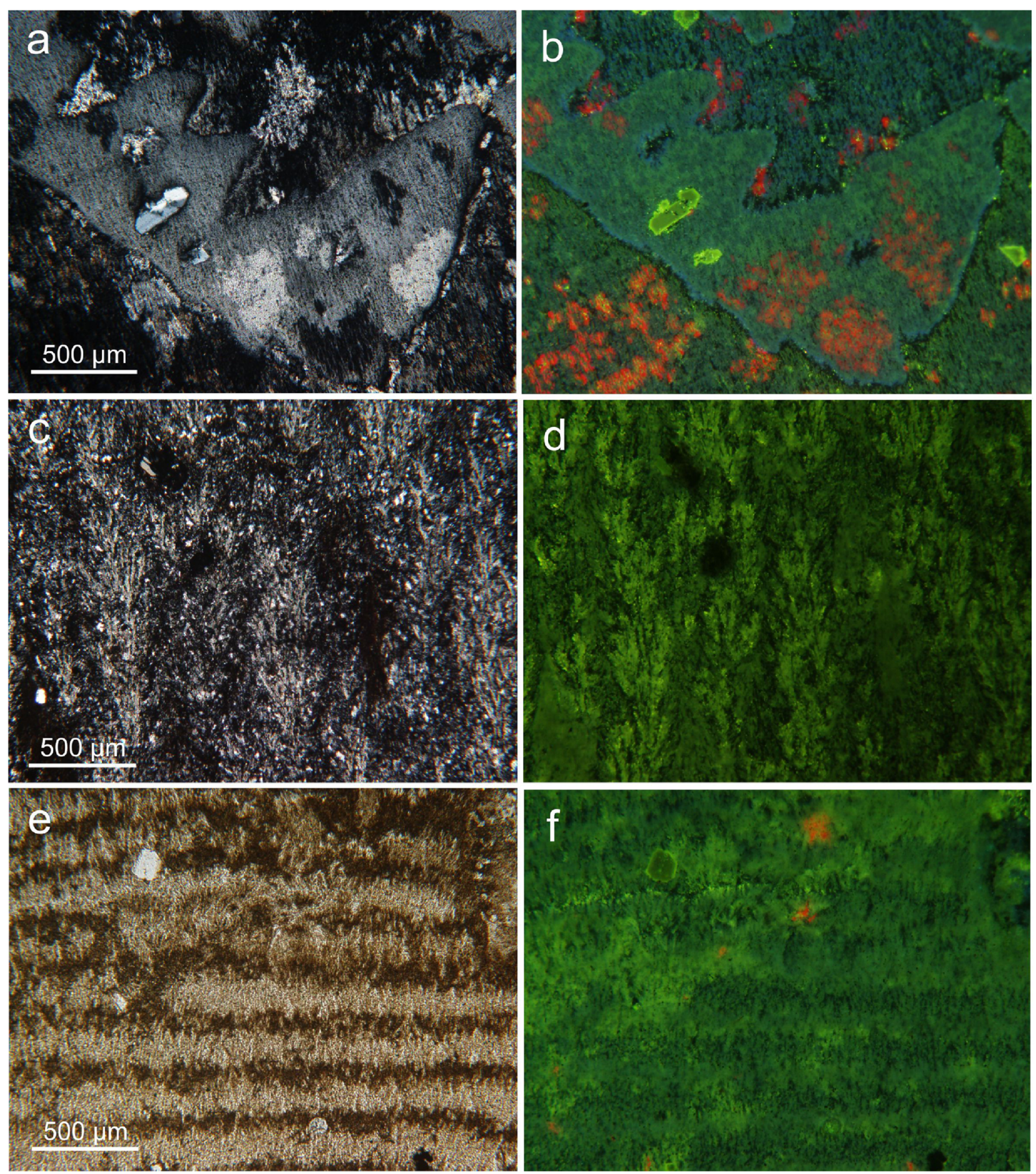

Fig. 9 Characteristic microtextures in the megaspherulite from Silver Cliff, CO (USA): a, b transmitted light (crossed polars) and CL micrograph pair showing texture T6 in the inner domain (ID) with fanshaped aggregates of fibrous intergrowths of sanidine (green CL) and quartz (dark-blue CL); plagioclase phenocrysts are detectable by brightgreen CL; red spots are related to quartz with abundant defects (compare

CL spectra in Fig. S3); c, d transmitted light (crossed polars) and CL micrograph pair in the outer domain (OD) showing intergrowth of dendritic sanidine (green CL), quartz (dark-blue CL), and smectite (no CL) with alignment perpendicular to the megaspherulite margin; $\mathbf{e}, \mathbf{f}$ transmitted light and CL micrographs illustrating autocyclic growth banding (T9) in the marginal domain (MD) 
texture, oriented perpendicular to the megaspherulite's outer rim (T7; Fig. 4a). T6 dendritic aggregates occur subdominantly. Up to 10 -mm-wide radiate crevasses are filled with sector- to full-sphere spherulites and lithophysae or macrocrystals of quartz and sanidine (T10; Figs. 4a, 5, and S1e, f).

Moreover, the marginal domain (MD) of SCM is dominated by a typical fine-grained, porous matrix showing autocyclic growth banding (some mm wide) with fibrous crystals of quartz and sanidine oriented perpendicular to the growth banding (T9-Fig. 9e, f). The SCM surface shows centimeter-sized sector-sphere, fibrous spherulites $(\boldsymbol{T 1 2})$. Noteworthy is the presence of fluorite in fissures and pores of the megaspherulite, detected by CL (Fig. S1g, h).

\section{El Quevar, Quirón/Salta Province (Argentina)}

\section{Whole-rock mineralogy and chemistry}

EQM is hosted by perlitic pitchstone. SEM-EDX analysis shows that the green-gray clay mineral in the amorphous glass is smectite. The host rock contains obsidian domains ("Apache's tears"; $\leq 4 \mathrm{~cm}$ ), and a few small plagioclase and biotite phenocrysts. EQMs have diameters of several decimeters up to $0.7 \mathrm{~m}$. The boundary between the inner and outer domains of EQM is sharp (Fig. 2). ID is characterized by void cavities (T2). Flow foliation (T1) has been observed throughout EQM. The chemical compositions of different parts of the megaspherulites from El Quevar are presented in Table 2; the rocks are rhyolites (Fig. 6).

The chemical composition of the different megaspherulite zones is relatively uniform, but shows minor chemical variation for selected elements. The outer megaspherulite domain (OD) has a lower $\mathrm{SiO}_{2}$ and higher $\mathrm{Al}_{2} \mathrm{O}_{3}$ content compared to the ID, and it is also slightly enriched in $\mathrm{CaO}, \mathrm{MgO}$, and $\mathrm{Fe}_{2} \mathrm{O}_{3}$. The comparison of the chemical composition of megaspherulites and host rock perlite/obsidian reveals remarkably higher concentrations of $\mathrm{SiO}_{2}$ and slightly depleted $\mathrm{K}_{2} \mathrm{O}$ and $\mathrm{Al}_{2} \mathrm{O}_{3}$ contents in the megaspherulites (Fig. 7).

The mineral composition of the fine-grained megaspherulites is dominated by $\mathrm{K}$-feldspar (sanidine) and Ca-poor plagioclase (andesine; Table 3 and Fig. S6). Plagioclase, sparse sanidine, and biotite occur as phenocrysts. Revealed by XRD, quartz content is generally low; instead, silica phases are dominated by cristobalite, tridymite, and opal-CT. This is in sharp contrast to SCM and MLM. Smectite represents a first alteration product of the volcanic rock, almost exclusively present in the outer domain (OD). Accessory minerals are magnetite, ilmenite, zircon, apatite, and aluminosilicates (possibly andalusite; Fig. 11e, f).

\section{Microtexture and in situ mineral composition}

The fine-grained matrix of the inner domain (ID) in the megaspherulites from El Quevar consists of K-feldspar (sanidine), plagioclase, and different $\mathrm{SiO}_{2}$ phases (cristobalite, tridymite, opal-CT, quartz) and may show a random or aligned distribution of microcrystals (Fig. 10c, d). The chemical composition of sanidine is similar in all domains of the EQM megaspherulite and varies between $\mathrm{Or}_{77} \mathrm{Ab}_{23} \mathrm{An}_{0}$ and $\mathrm{Or}_{35} \mathrm{Ab}_{59} \mathrm{An}_{6}$ (Figure S6 and Table S1). The matrix Kfeldspar often shows a Na-rich core. It has to be noted that sanidine in the inner domain mostly shows a green CL due to $\mathrm{Mn}^{2+}$ activation (similar to SCM), whereas sanidine in the outer domain lacks $\mathrm{Mn}$ incorporation and shows a brightblue CL (compare spectra in Figs. S2 and S4).

Flow texture is visible due to aligned microlites and dendritic minerals ( $\boldsymbol{T} \boldsymbol{1}$-Figs. $4 \mathrm{c}$ and $10 \mathrm{a}, \mathrm{b})$. The alternation of areas with smectite interlayers and smectite-free areas causes a flaky microtexture. Moreover, phenocrysts of plagioclase, biotite, and radial crystal aggregate of K-feldspar (Fig. S3a, b) are embedded in the matrix. The phenocrysts of Na-rich plagioclase (oligoclase-andesine) with a chemical composition between $\mathrm{An}_{39} \mathrm{Ab}_{58} \mathrm{Or}_{3}$ and $\mathrm{An}_{14} \mathrm{Ab}_{79} \mathrm{Or}_{7}$ (Fig. S6 and Table S1) stand out due to their bright-greenish-yellow CL colors and sometimes exhibit distinct growth zoning (Fig. 10b). The matrix also shows a spherulitic to lithophysa texture (T4) and crescent-shaped domains (Fig. S3c, d). Layered textures of sanidine, plagioclase, and $\mathrm{SiO}_{2}$ phases occur in the outer part of the ID. The distribution of the different minerals can only be distinguished by CL (Fig. 10c, d).

The transition zone from inner to outer domain (OD) in EQM shows a change from a layered texture of different feldspar and silica phases to a texture with feldspar-quartz microspherulites (Figs. 10e, f and 11a, b). The feldsparquartz spherulites often consist of a core of Na-rich plagioclase embedded in a matrix of sanidine, but $\mathrm{SiO}_{2}$ spherulites were also observed (Fig. 11b).

Continuing in the direction of the crystallization front, the marginal domain (MD) is characterized by fibrous feldspar and $\mathrm{SiO}_{2}$ minerals with dendritic smectite interlayers (T14; Figs. 4d and S3e, f). The clay minerals form fan-shaped and palisade-like domains. The crystallites and fibers are arranged perpendicular to the outer skin of the megaspherulite. The SEM analysis shows intimate intergrowths of feldspar and $\mathrm{SiO}_{2}$ phases with accessory minerals (Fig. 11c) as well as varying microtextures of different silica minerals (quartz, cristobalite, tridymite, opal-CT; Fig. 11d). Inside T14, chevron-shaped cavities formed, with the concave sides oriented outwards (T15; Fig. 4d; see also Fig. 6d in Breitkreuz 2013). Some cavities have been filled with secondary minerals (Fig. 13g).

Laterally replacing $\boldsymbol{T} \mathbf{1 4}$, MD of EQM shows domains of autocyclic growth banding with fibrous crystals of quartz, sanidine, and Na-rich plagioclase oriented perpendicular to 

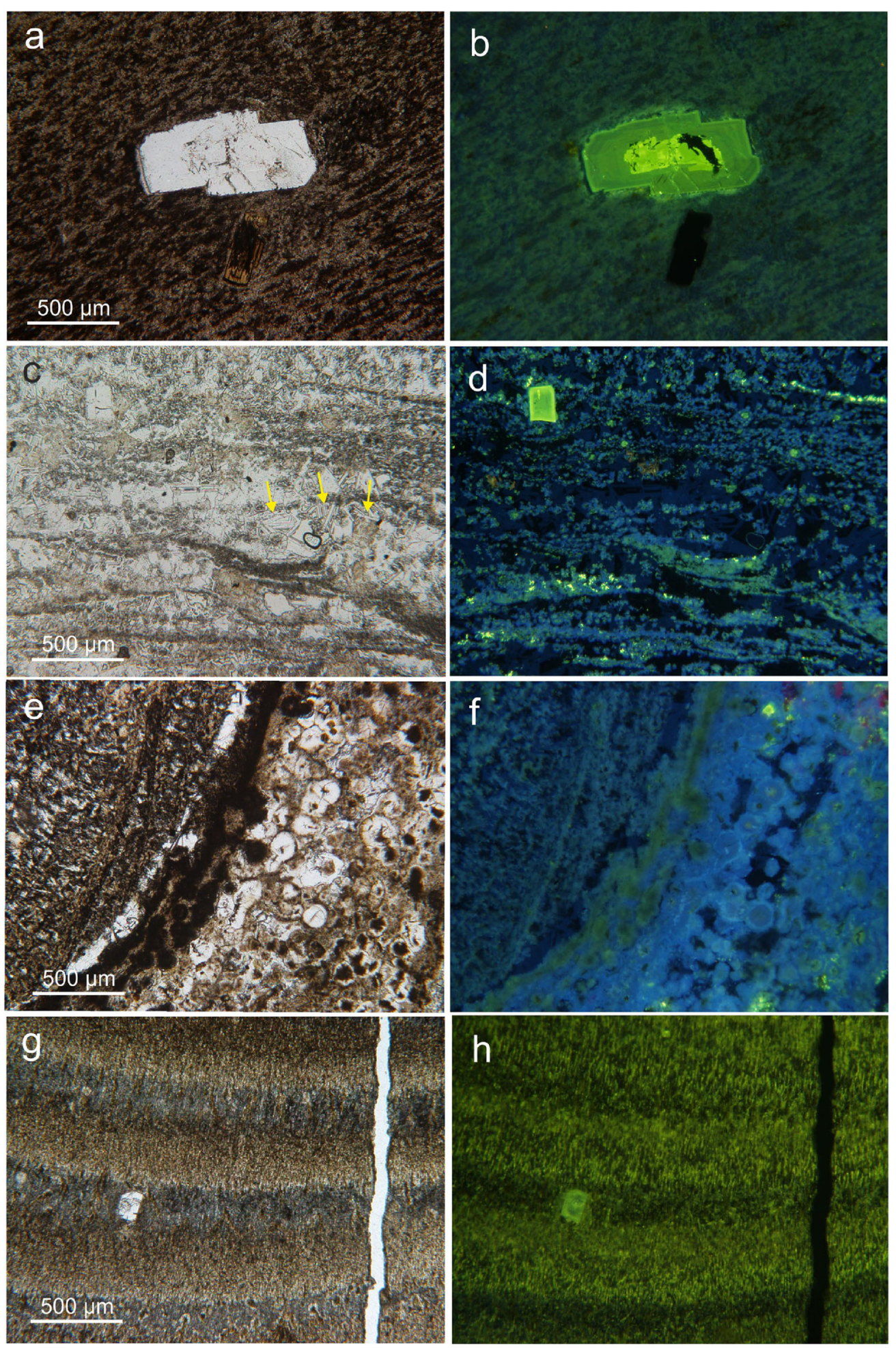

Fig. 10 Transmitted light and CL micrographs of characteristic microtextures of megaspherulites from El Quevar (Argentina): $\mathbf{a}, \mathbf{b}$ flow foliation in a matrix of $\mathrm{SiO}_{2}$ phases and feldspar (texture T1) with zoned plagioclase (green CL) and biotite phenocrysts in the inner domain (ID); $\mathbf{c}, \mathbf{d}$ plagioclase phenocryst in a layered texture (flow texture) of sanidine (bright-blue CL), plagioclase (green $\mathrm{CL}$ ), and $\mathrm{SiO}_{2}$ phases (dark-blue $\mathrm{CL}$ ); note cristobalite/tridymite laths (yellow arrows); e, f transition zone from the inner (ID) to the outer domain (OD) with a layered texture of sanidine (blue CL), plagioclase (green CL-see CL spectra in Fig. S4), and $\mathrm{SiO}_{2}$ phases (dark-blue $\mathrm{CL}$ ) and micro-spherulitic texture (feldspar and quartz spherulites); $\mathbf{g}, \mathbf{h}$ top area of the megaspherulite (MD) showing autocyclic growth banding (T9) with varying dominance of sanidine and Na-rich plagioclase (green CL) and $\mathrm{SiO}_{2}$ phases (dark layers in CL) and few plagioclase phenocrysts 

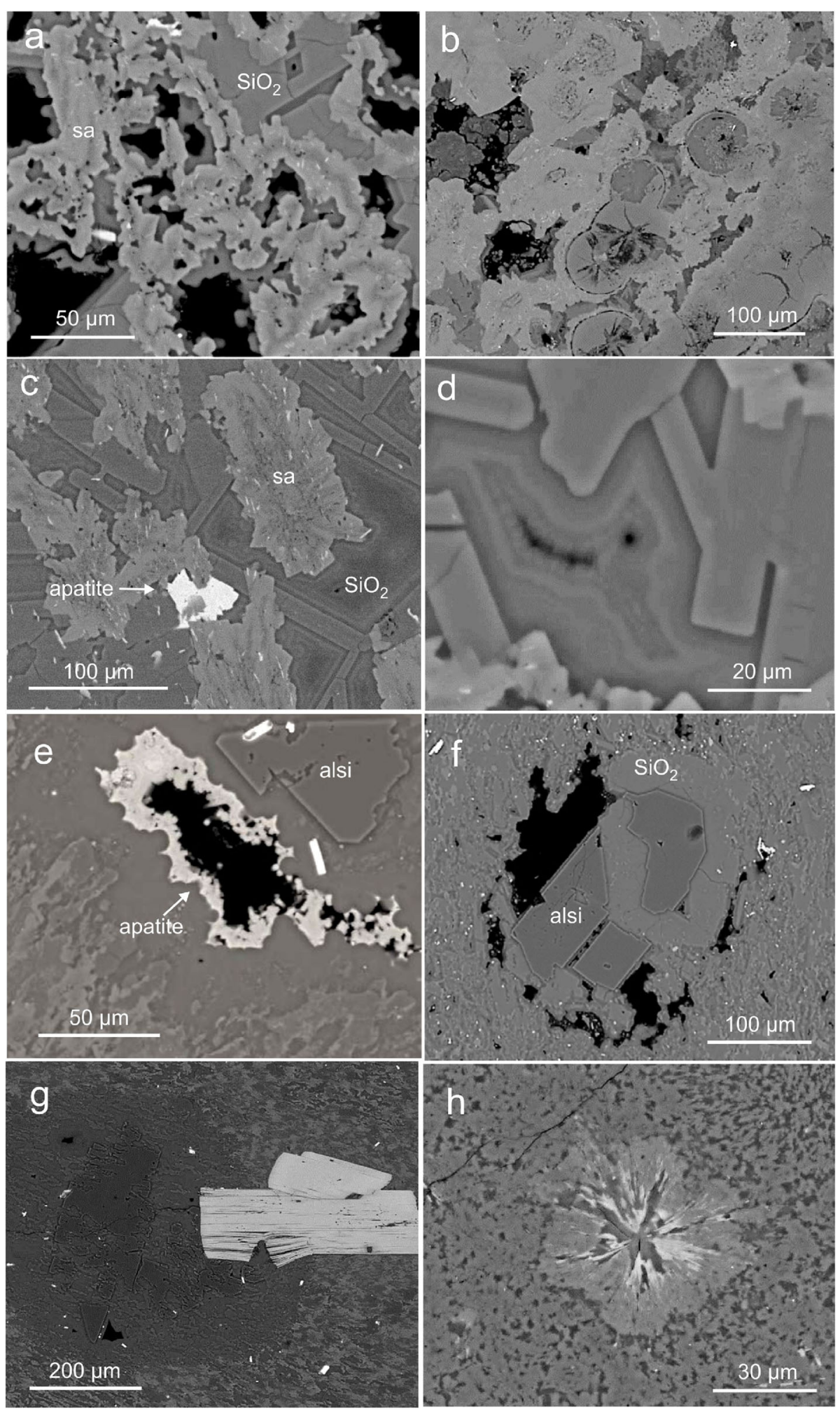

Fig. 11 SEM (BSE) micrographs showing details of the microtexture and minerals in megaspherulites from El Quevar (Argentina): a aggregate of $\mathrm{SiO}_{2}$ minerals and sanidine (sa) with Na-rich core and K-rich rim; $\mathbf{b}$ formation of microspherulites of Na-rich feldspar within the fine-grained sanidine matrix (compare Fig. 10e, f); c small apatite in a matrix of

microtexture of different $\mathrm{SiO}_{2}$ phases; e heterogeneous apatite aggregate in the pore space beside aluminosilicate (alsi); $\mathbf{f}$ intergrowth of aluminosilicate (alsi-andalusite?) and $\mathrm{SiO}_{2} ; \mathbf{g}$ biotite phenocryst intergrown with aluminosilicate and silica phase close to the top of the crystallization front; $\mathbf{h}$ spherulitic aggregate with Fe-rich biotite core intergrown with Na-rich sanidine 
the growth banding (T9-Fig. 10g, h). Some fractures occur in MD which are partly filled with secondary minerals such as opal and chalcedony as well as carbonates (calcite - see Fig. $\mathrm{S} 3 \mathrm{~g}, \mathrm{~h}$ ). The $\mathrm{SiO}_{2}$ layers show a bright-green CL related to the activation of uranyl ions $\left(\mathrm{UO}_{2}{ }^{2+} ; \mathrm{Fig}\right.$. S4b).

The surface of the megaspherulite shows centimeter-sized fibrous spherulites (T12). Furthermore, cone-shaped dimples with radiate grooves (T13) are scattered over the surface, which are almost completely filled with crystal fibers oriented perpendicular to the outer skin of the megaspherulite (see Fig. $5 \mathrm{f}$ in Breitkreuz 2013).

Certain accessory minerals have been detected in the finegrained matrix of the megaspherulites. The groundmass contains plagioclase and biotite phenocrysts. Up to $3.0 \mathrm{wt} \% \mathrm{Ti}$ was measured in biotite crystals. Interestingly, biotite occurs not only as large crystals (Fig. 11g), but also as fine needles in the matrix as well as in spherulitic aggregates intergrown with sanidine (Fig. 11h). Sporadically, crystal aggregates of aluminosilicates (andalusite?) and calcium phosphate (apatite) have been detected (Fig. 11e, f). Complex phosphates occur also as thin covers of clay minerals (smectite). The occurrence and textural features of these mineral phases along with the presence of smectite and secondary silica might indicate alteration and overprint during final cooling or secondary fluid activity.

\section{Triebischtal near Meissen, Saxony (Germany; MLM)}

\section{Whole-rock mineralogy and chemistry}

The investigated megaspherulite from Triebischtal near Meissen (MLM) has a diameter of ca. $90 \mathrm{~cm}$ and was originally embedded in pitchstone, which is indicated by adhering residues of greenish pitchstone and smectite on MD (Fig. 3). The pitchstone exhibits characteristic perlitic cracks and has been partly devitrified and altered to fine-grained quartz (46.6 $\pm 0.7 \mathrm{wt} \%)$, orthoclase $(41.6 \pm 0.7 \mathrm{wt} \%)$, and dioctahedral Nasmectite (11.9 $\pm 0.9 \mathrm{wt} \%)$ (Lange and Heide 1996). The Triebischtal pitchstone, in general, contains only a few phenocrysts of quartz and K-feldspar, the latter often altered (Jentsch 1981). LOI of our small pitchstone sample is 1.96 wt\%; however, Lange and Heide (1996) measured 5.6 wt\% for the MLM host.

The more or less uniform chemical composition of different parts of the MLM is presented in Table 2 showing an acidic volcanic rock with rhyolitic composition (Fig. 6). The comparison of the MLM composition with the hosting pitchstone reveals slightly higher concentrations of $\mathrm{SiO}_{2}$, $\mathrm{K}_{2} \mathrm{O}$, and $\mathrm{Na}_{2} \mathrm{O}$ in the megaspherulite. The pitchstone is enriched in $\mathrm{CaO}, \mathrm{MgO}$, and $\mathrm{Fe}_{2} \mathrm{O}_{3}$ (Fig. 7).

The major mineral composition of MLM is simple and consists only of quartz and two types of sanidine (Table 3). Accessory minerals are ilmenite and zircon. Sanidine dominates the matrix and is also present as phenocrysts with varying chemical composition between $\mathrm{Or}_{99} \mathrm{Ab}_{1}$ and $\mathrm{Or}_{62} \mathrm{Ab}_{38}$ and without detectable Ca content (Figure S6 and Table S1). The fine-grained and spherulitic matrix mostly comprises intergrowth of sanidine and quartz. Sanidine phenocrysts often show higher $\mathrm{K}$ content compared to groundmass sanidine. Thin rims of $\mathrm{K}$-feldspar surrounding the quartz spherulites are almost Na-free.

\section{Microtexture and in situ mineral composition}

MLM is characterized by a heterogeneous inner domain (ID) containing a decimeter-sized cavity filled with quartz $(\boldsymbol{T} 2)$ and sector- to full-sphere spherulites (T4; Figs. 3 and 4f). The outer domain (OD) is dominated by concentric growth banding $(\boldsymbol{T} 9)$ superimposing flow foliation $(\boldsymbol{T 1})$, and crosscut by radiate to oblique crevasses (T10; Figs. $3,4 \mathrm{e}$, and 5b). The marginal domain (MD) terminates with centimeter-sized fibrous, sector-sphere spherulites on the outer skin of the megaspherulite (T12).

T4 of the MLM inner domain (ID) consists of sanidine with bright-blue CL and quartz with dark-blue CL (Fig. $12 \mathrm{a}, \mathrm{b})$. Several areas show crystal aggregates of quartz and $\mathrm{K}$-feldspar and small spherulites irregularly distributed in a fine groundmass (T5; Figs. 13a and S5a, b). SEM measurements reveal that the quartz spherulites are covered by small rims of Na-poor K-feldspar. Aggregates of quartz with a high defect density (non-bridging oxygen-hole center [NBOHC]; StevensKalceff 2009) are detectable due to their reddish CL (Fig. S5b). In the transition zone to the outer domain, the microspherulites of quartz (and sanidine) show a layered arrangement and are embedded in a flow texture (T1; Fig. 12c, d).

A specific textural feature is developed along a large quartz-filled cavity (T2; Fig. S5c, d). Quartz and scarce sanidine crystals of different sizes are heterogeneously distributed in this zone forming subareas with varying microtextures. In addition, the sanidine phenocrysts show heterogeneous internal textures (Fig. 13b). Both groundmass sanidine and phenocrysts exhibit a brightblue CL. The comparison of their CL spectra reveals the same emission bands, but the groundmass sanidine has more structural $\mathrm{Fe}^{3+}$ (Fig. 13c).

The most frequent microtexture in the outer domain (OD) of MLM is a concentric autocyclic growth banding (T9; Figs. $4 \mathrm{e}$ and S5e, f) with several millimeter thick bands overprinting flow foliation texture $(\boldsymbol{T} 1)$. The fibrous crystals of sanidine and quartz are oriented in growth direction perpendicular to the banding, and they show blotchy extinction in polarized light.

OD and MD are crosscut by crevasses which are filled with microcrystalline quartz, feldspar, and fibrous spherulites and lithophysae (T10; Figs. 3 and 12e, f). Also, larger spherical 

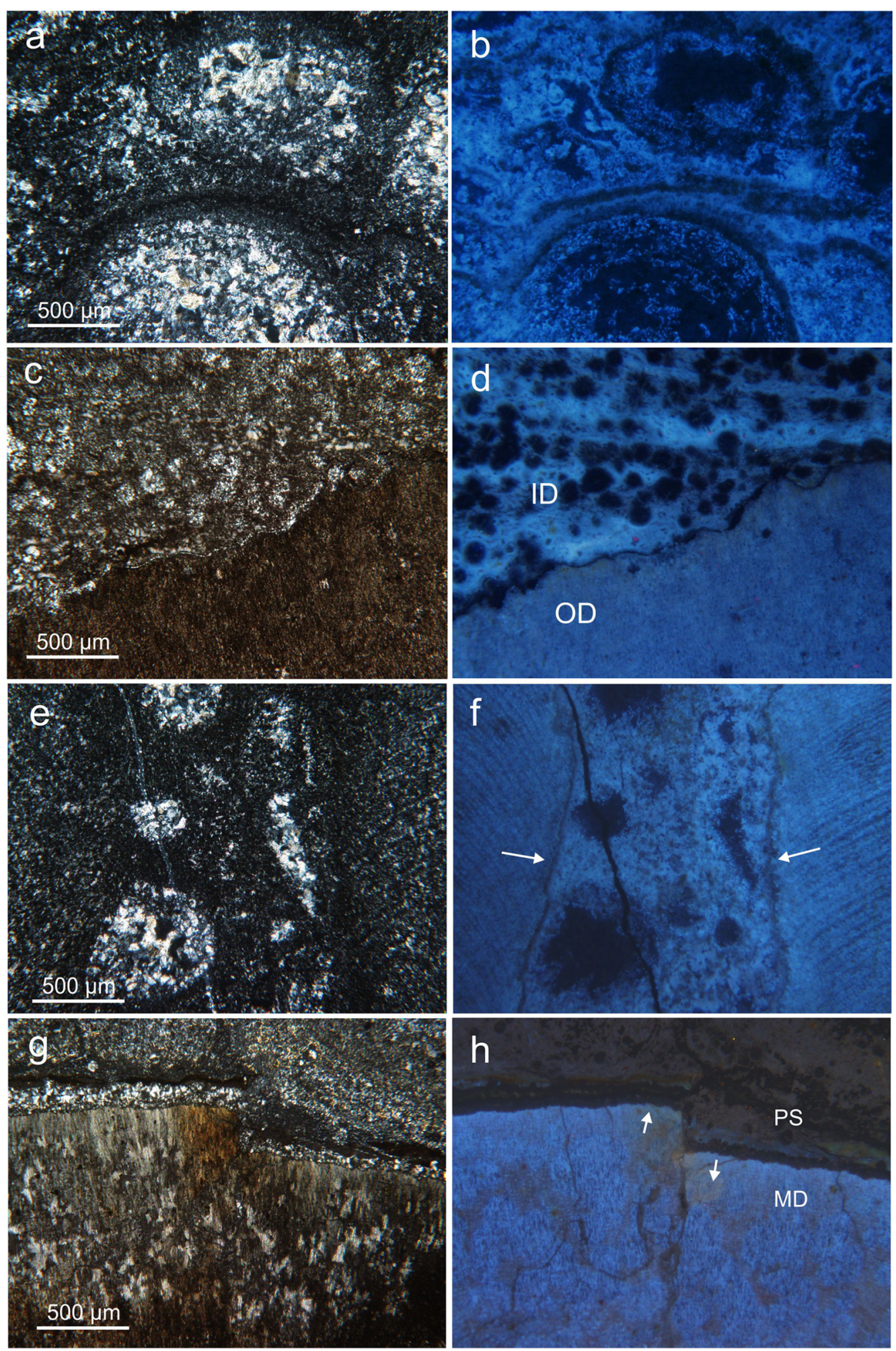

Fig. 12 Transmitted light (crossed polars) and CL micrograph pairs showing characteristic microtextures in the megaspherulite from Triebischtal (MLM): a, b sector- to full-sphere spherulites with concentric internal zonation (texture T4) consisting of sanidine (bright-blue CL) and quartz (dark-blue CL) in the inner domain (ID); $\mathbf{c}, \mathbf{d}$ Transition zone between the inner (ID) and outer domains (OD) showing a layered

arrangement of quartz spherulites (dark-blue CL) in a flow texture dominantly consisting of sanidine; $\mathbf{e}, \mathbf{f}$ radiate crevasse (T10) crosscutting the autocyclic growth banding (see arrows) in the outer domain (OD); the interspace is filled with fine-grained sanidine and quartz as well as spherical aggregates of quartz (dark-blue CL); $\mathbf{g}, \mathbf{h}$ brecciation and dislocation (arrows) of the outermost part of MD in contact to pitchstone (PS) 

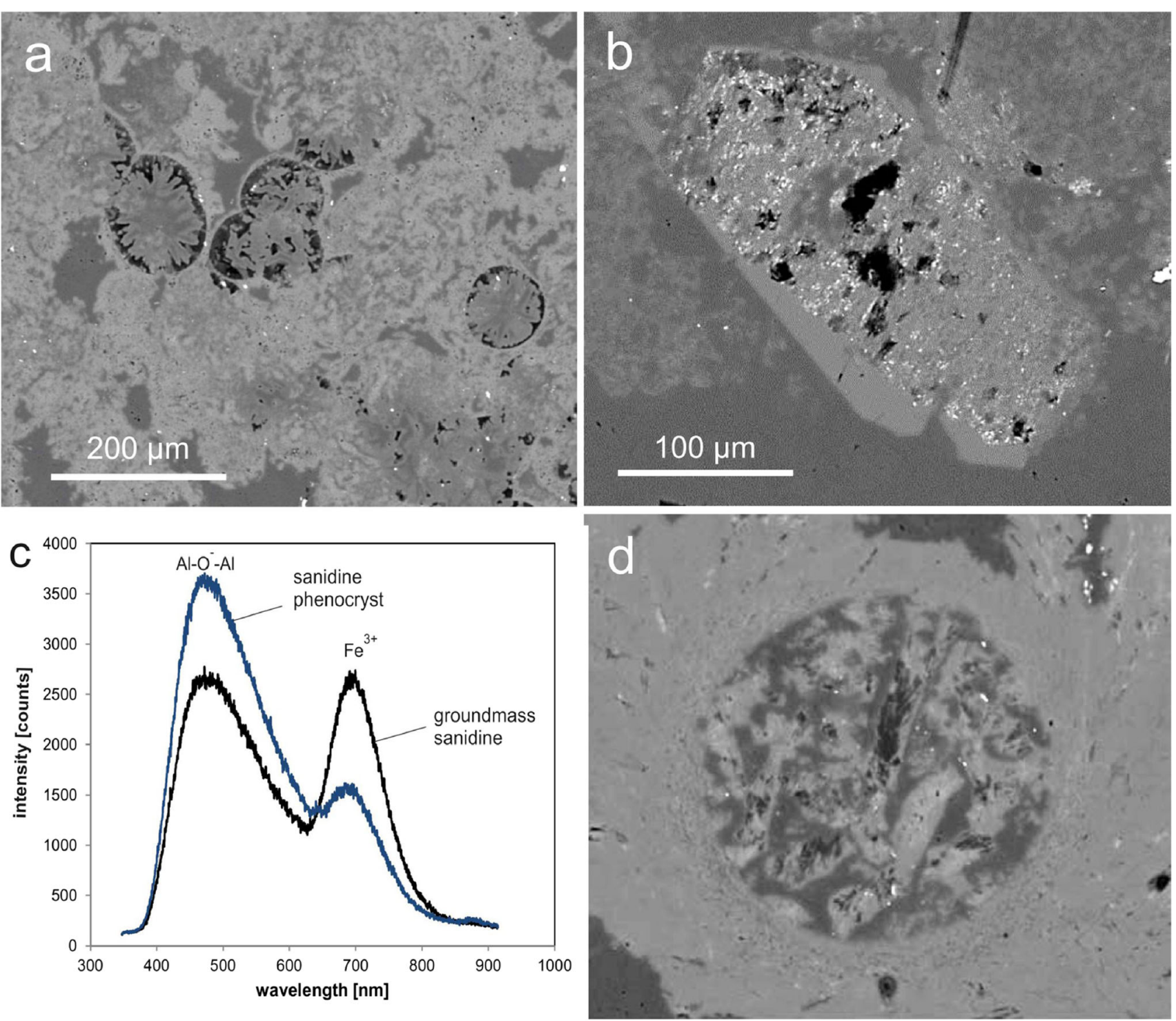

Fig. 13 SEM (BSE) micrographs and CL spectra showing details of the microtexture and minerals in the megaspherulite from Triebischtal (Germany): a microspherulites of quartz with small rims of Na-poor Kfeldspar in a matrix of sanidine (T5) in the inner domain (ID; compare Fig. S5a, b); b sanidine phenocryst (15.03 wt\% K) with a heterogeneous

aggregates of microcrystalline quartz have been observed. The texture indicates intrusion of melt into cracks. Figure $5 \mathrm{~b}$ shows that the hosting domain ( $(\boldsymbol{T} 9)$ was bent during the intrusion. Ductile deformation of T9 presumably was facilitated by the presence of small melt domains (later on transition to glass and smectite or quartz/sanidine took place). Investigations under high magnification revealed complex internal textures and quartz-sanidine intergrowth in the spherulites (Fig. 13d). In places, the brecciated crevasses are cemented by secondary quartz. Preferred orientation of the crevasses and a common dextral offset of hosting OD (Fig. 3) indicate shearing of the MLM, presumably during late lava movement.

texture in the inner domain (ID); $\mathbf{c}$ CL spectra of groundmass sanidine and of a phenocryst; both show visible bright-blue CL and the same emission bands, but the groundmass sanidine has more structural $\mathrm{Fe}^{3+}$; d details of a spherulitic area in a radiate crevasse in the marginal domain (MD) close to the megaspherulite skin (compare Fig. S5a, b)

In the marginal domain (MD) close to the surrounding pitchstone, centimeter-sized fibrous sector-sphere spherulites developed (T12). These spheres may have a zoned structure with varying microtextural features (Fig. S5g, h). The crevasses $(\boldsymbol{T 1 0})$ observed in OD also crosscut and dislocate MD (Figs. 3b, 4e, and 12g, h).

\section{Discussion}

Based on our results, we propose that the 15 different types of microtextures and their mineralogies are controlled by whole- 
rock chemical composition and temperature. Primary crystallization in the cooling melt (mainly sanidine and $\mathrm{SiO}_{2}$ phases) took place above $T_{\mathrm{g}}$. Compositional differences between ID and $\mathrm{OD}$ (in SCM and $\mathrm{EQM}$ ) and between the megaspherulites and their host are then related to elements expelled during growth, and later $\mathrm{H}_{2} \mathrm{O}$ intake. Below $T_{\mathrm{g}}$, and in the course of complete cooling as well as later during diagenesis, an array of secondary minerals formed. Based on these results and interpretations, we present a model which attempts to describe the complex growth history of the three megaspherulites.

\section{Chemistry and mineralogy of megaspherulites}

The chemical composition of the investigated megaspherulites illustrates that they formed exclusively in acidic lava with rhyolitic composition (Fig. 6). In general, the mineral composition of the megaspherulites is dominated by $\mathrm{K}$-feldspar (sanidine) and $\mathrm{SiO}_{2}$ phases (quartz, cristobalite), although slight differences in the whole-rock chemistry of the different occurrences are caused by variations in the quantitative mineral abundances (Fig. 7).

The megaspherulite from Triebischtal (MLM) has the highest contents of $\mathrm{SiO}_{2}$ and $\mathrm{K}_{2} \mathrm{O}$, and the lowest $\mathrm{Al}_{2} \mathrm{O}_{3}, \mathrm{CaO}$, and $\mathrm{Na}_{2} \mathrm{O}$ concentrations (Fig. 7). Accordingly, MLM has a simple mineral composition consisting of the high-temperature K-feldspar phase sanidine and quartz. In contrast, elevated concentrations of $\mathrm{CaO}$ and $\mathrm{Na}_{2} \mathrm{O}$ in $\mathrm{SCM}$ and $\mathrm{EQM}$ reflect the presence of Na-rich plagioclase (oligoclase-andesine) both as phenocrysts and within the fine-grained matrix. In addition, the marginal zone of SCM reveals distinct changes in chemical composition and mineralogy (Tables 2 and 3). There is an outwards oriented tendency of decreasing $\mathrm{SiO}_{2}$ and increasing $\mathrm{Al}_{2} \mathrm{O}_{3}$ concentration resulting in the outer sanidine-quartz rind, which was already reported by Smith et al. (2001).

A peculiar feature of the megaspherulites from $\mathrm{El}$ Quevar is the dominance of $\mathrm{SiO}_{2}$ modifications such as cristobalite, tridymite, and opal-CT instead of quartz. The lowtemperature opal-CT indicates formation from an amorphous silica precursor. Cristobalite and tridymite formation in EQM probably was favored by undercooling of the melt preventing the regular crystallization of quartz (Perrotta et al. 1989; Baxter et al. 1999; Zawrah and Hamzawy 2002). Horwell et al. (2013) also discussed the formation of prismatic and platy forms of vapor-phase cristobalite in pores and fractures of volcanic rocks at the Soufrière Hills Volcano, Montserrat.

Ilmenite is a frequent accessory mineral in all megaspherulites as reflected by the measured $\mathrm{TiO}_{2}$ concentration (Table 2). Local chemical analyses of the rock-forming minerals revealed that elevated contents of Ti can also be incorporated in biotite and feldspar (especially sanidine; Table S1). Variations in the iron content of the megaspherulites are often visible by staining effects of the rocks due to iron oxides/hydroxides. However, iron is not only a constituent of iron phases and iron-bearing minerals (e.g., biotite, smectite). Spectral CL measurements also revealed structural incorporation of $\mathrm{Fe}^{3+}$ at $\mathrm{Al}^{3+}$ position in feldspar minerals (Figs. S2 and S4).

The comparison of the chemical composition of the megaspherulites and of the surrounding host (obsidian, perlitic pitchstone) illustrates that during crystallization, there was some movement of elements from the megaspherulite into the cooling melt and vice versa (Fig. 7 and Table 2). The megaspherulites from Silver Cliff show an enrichment of $\mathrm{SiO}_{2}$ and $\mathrm{K}_{2} \mathrm{O}$ as well as depletion in $\mathrm{Na}_{2} \mathrm{O}$ compared to the surrounding vitrophyre. Assuming a homogeneous melt during emplacement, the chemical variation must have developed during the crystallization of quartz and sanidine in the megaspherulite, and an exclusion of $\mathrm{Na}_{2} \mathrm{O}$ into the host. Such chemical fractionation is also documented for $\mathrm{EQM}\left(\mathrm{SiO}_{2}\right.$ enrichment and $\mathrm{Al}_{2} \mathrm{O}_{3}$ depletion) and MLM $\left(\mathrm{SiO}_{2}\right.$ and slight $\mathrm{K}_{2} \mathrm{O}, \mathrm{Na}_{2} \mathrm{O}$ enrichment). Chemical differences between megaspherulite and pitchstone host might also be partially attributed to mineralized external water causing secondary compositional alteration of the glass. However, for EQM, a comparison of perlite and obsidian displays pure water input (Table 2).

Our whole-rock analyses of the SCM hosting pitchstone (LOI 5.27-5.69 wt\%; Table 2) confirm the high $\mathrm{H}_{2} \mathrm{O}$ content stated by Smith et al. (2001: $7.6 \mathrm{wt} \%$ ). Smith et al. (2001) considered the high $\mathrm{H}_{2} \mathrm{O}$ content as of magmatic origin. However, Quaternary obsidian lava and domes present in Western US yielded $\mathrm{H}_{2} \mathrm{O}$ content of $\leq 0.5 \mathrm{wt} \%$ (DeGroatNelson et al. 1999). Despite the low volatile content, these complexes developed extended vesiculated domains due to supersaturation (Fink 1983) rendering unlikely a formation of a rhyolitic lava flow with $7 \mathrm{wt} \% \mathrm{H}_{2} \mathrm{O}$ without vesiculation or explosive eruption. As a consequence, we assume that the transformation of the SCM glass host to a pitchstone took place late during or after cooling. This conclusion is supported by the analyses of the other megaspherulite occurrences. The obsidian ("Apache's tears") surrounding EQM has a LOI of $0.76 \mathrm{wt} \%$ pointing to the low water content of the original melt. The LOI of $3.64 \mathrm{wt} \%$ of the related perlitic pitchstone can be explained by secondary water uptake during alteration. The elevated LOI of $1.96 \mathrm{wt} \%$ (5.6 wt\%: Lange and Heide 1996) of the partially crystallized pitchstone of the MLM indicates similar processes.

\section{Primary vs. secondary mineral formation}

A common feature of both the megaspherulites and the surrounding host rocks is the presence of clay minerals (smectite, Table 3 and SEM-EDX data). Furthermore, accessory minerals were observed such as garnet (Fe-rich spessartine) and fluorite in SCM, or aluminosilicates (likely andalusite) and phosphates in EQM. Accordingly, the question arises concerning primary and secondary 
crystallization processes during megaspherulite formation. Assuming that certain phenocrysts (quartz, feldspar, biotite) and accessory minerals (ilmenite, magnetite, zircon) already crystallized in the magma chamber and were present in the melt before emplacement of the lava, a definition of different mineralization processes needs to consider the following formation stages:

$\rightarrow$ Primary: crystallization from the melt above $T_{\mathrm{g}}$ $\rightarrow$ Secondary: formation during the last phase of cooling below $T_{\mathrm{g}}$

$\rightarrow$ Alteration (weathering, diagenesis, and hydrothermal overprinting)

The common occurrence of primarily crystallized phenocrysts in both megaspherulites and the surrounding host rocks is evidence of their formation from the same melt. This conclusion is emphasized by the similar chemical composition of both. Textural aspects in the megaspherulites (presence of spherulites and fibrous crystals) emphasize that the crystallization of the fine-grained matrix consisting of feldspar (in particular sanidine) and quartz (or other silica phases) started above $T_{\mathrm{g}}$ and continued until the last phase of cooling.

The formation history of clay minerals (smectite) inside megaspherulites and other HTCD seems to be complex as already noted by Iddings (1885a, b). The presence of smectite in interstices between quartz and feldspar indicates that crystallization began during the late phase of cooling, when fluids caused the transformation of glass and/or unstable silicate minerals to clay minerals (autometasomatosis).

Smith et al. (2001) concluded that the clay-zeolite zone surrounding SCM resulted from fluid "enriched in $\mathrm{Ca}, \mathrm{Mg}$, and $\mathrm{Fe}$, and depleted in $\mathrm{Si}, \mathrm{K}$, and $\mathrm{Na}$," expelled from the growing megaspherulite to result in the hydrothermal alteration. Our measurements confirm these conclusions as the fluid-rock interaction is reflected not only in the formation of zeolite and clay minerals, but also in a complete overprint of the chemical composition of this zone with supply of $\mathrm{Al}_{2} \mathrm{O}_{3}, \mathrm{Fe}_{2} \mathrm{O}_{3}, \mathrm{CaO}$, and $\mathrm{MgO}$ and removal of soluble components such as $\mathrm{Na}_{2} \mathrm{O}$ and $\mathrm{K}_{2} \mathrm{O}$ (Table 2). Alteration of the MLM host is documented by smectite formation along perlitic cracks which took place during final cooling below $150{ }^{\circ} \mathrm{C}$ (Götze et al. 2020). However, subsequent clay mineral formation by hydrothermal overprint cannot be ruled out.

Evidence for high fluid activity during a late stage of megaspherulite crystallization is also provided by the presence of minerals such as garnet and fluorite in SCM, and aluminosilicates and phosphates in EQM. The textural features of the $\mathrm{Mn}$-garnet (Fe-rich spessartine) in SCM indicate an origin by late magmatic or secondary blastesis (displacement) in the megaspherulite matrix. Smith et al. (2001) argued for a secondary origin of garnet because of (1) the lack of garnet in the host-rock vitrophyre, (2) the generally low Mn content of the megaspherulite (low compared to the surrounding vitrophyre), and (3) the enrichment of $\mathrm{Mn}$ dendrites along fractures (along with the high porosity of the megaspherulite). This conclusion is supported by the present study, since the manganese distribution in the megaspherulites is heterogeneous. We found areas containing less or no garnet, where $\mathrm{Mn}$ incorporation was also not detectable in sanidine (common blue CL), and those containing spessartine as well as sanidine with $\mathrm{Mn}^{2+}$ activated greenish CL pointing to a late supply of Mn-bearing fluids. The CL study revealed a high Mn concentration in the primary melt. However, Mn intake into crystallizing sanidine is limited due to crystal-chemical aspects. Restitic fluids became $\mathrm{Mn}$ oversaturated leading to the formation of Mn-garnet. The high Mn content in late fluids is supported by light-green secondary CL rims and fractures in plagioclase phenocrysts due to high $\mathrm{Mn}^{2+}$ activation (Fig. S2b).

The detection of fluorite along fractures and/or cavities is another evidence for its late formation by fluids within permeable zones in EQM. The local occurrence and textural characteristics of aluminosilicates and phosphates indicate their formation by migrating secondary fluids in zones of high permeability.

ID OD/MD

\section{SCM}

EQM
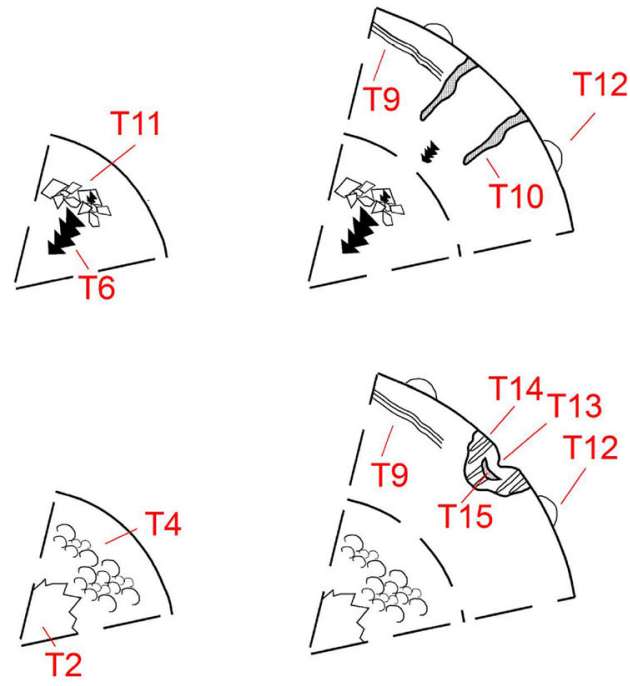

\section{MLM}
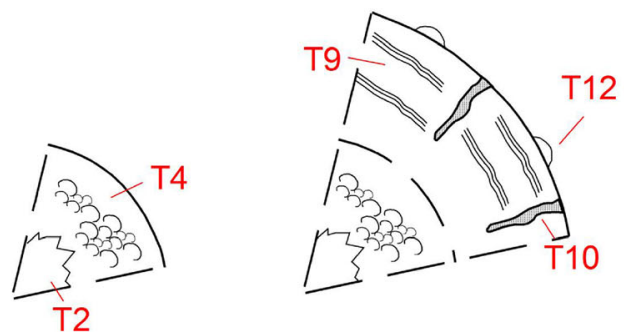

Fig. 14 Schematic sketches of the growth of SCM, EQM, and MLM with the dominant textures in ID and OD/MD; for the sketches on the right, approx. radius is $100 \mathrm{~cm}$ for SCM, $35 \mathrm{~cm}$ for EQM and $45 \mathrm{~cm}$ for MLM 


\section{Textural features in megaspherulites}

A general feature of all megaspherulites is that they do not represent single large spherulites, but they comprise compound crystallization domains consisting of at least three zones with different growth patterns and specific texture assemblages (Table 1 and Fig. 14).

\section{Early megaspherulite growth}

EQM and MLM developed similar textures during early growth (central cavities and sector- to full-sphere spherulites, $\boldsymbol{T} 2$ and $\boldsymbol{T} 4$; Fig. 14), the latter aligned along flow foliation (T1). In contrast, SCM formed dendritic quartz-feldspar domains and brecciation $(\boldsymbol{T} 6, \boldsymbol{T} 11)$. The dendritic domains consist of bundles of fibrils each radiating from a single point. Dendritic textures occur when crystal growth is accompanied by an unstable growth front. Growth is favored in a distinct direction characterized by a high growth rate (Kobayashi 1993; Trivedi and Kurz 1994). Nucleation and continuing growth are controlled by changes in the local temperature gradient (Keith and Padden 1963). In places, the outer part of ID in SCM is strongly brecciated (T11) presumably as the consequence of local fluid overpressure. Some of the T11 fragments display unfragmented T6, indicating that brecciation took place early before dendritic growth (Fig. 4b).

\section{Late and final megaspherulite growth}

A common feature of OD and MD of all three megaspherulites is autocyclic banding (T9), whereas this texture is most prominent in MLM (Fig. 14). It comprises fibrous, radially oriented sanidine and quartz, $\leq$ $100 \mu \mathrm{m}$. In case of SCM and EQM, it also contains smectite, presumably a product of devitrification. Iddings (1885a, b, 1891) and Castro et al. (2008) noted that radiating fibrous spherulites often contain interstitial glass and pores; the former could have been altered into smectite. Apparently, during the final phase of megaspherulite growth crystallization became more incomplete and more interstitial melt remained.

At a low temperature close to $T_{\mathrm{g}}$, slow diffusion from the melt to the crystallization front and back controlled cyclic growth and transient growth retardation (cf. Liesegang 1913; Allégre et al. 1981). The development of such autonomous patterns (T9) by geochemical selforganization is caused by coupling between the interface kinetics of growing crystals and the diffusion of the chemical species in the crystal-melt interface in an open system, often far from thermodynamic equilibrium (Holten et al. 2000). The temperature must have been still above $T_{\mathrm{g}}$ since melt moved into crevasses (T10) crosscutting OD dominated by autocycling banding (T9).

Lithophysae may break during late flow of lava or rheomorphic ignimbrite (Iddings 1887; Cas and Wright 1987; Holzhey 1994; Breitkreuz 2013). SCM and MLM display prominent crevasses (T10; Fig. 5). In places, the hosting OD and MD of MLM displays minor offset (dextral shear in MLM; Fig. 3) suggesting that the crevasses opened after formation of OD and MD. Presumably, melt surrounding the fully grown megaspherulite intruded (or was sucked in) and crystallized into fibrous spherulites. This also underlines that when MLM and SCM growth was completed, the megaspherulites were still hosted by melt above $T_{\mathrm{g}}$. The melt located close to the megaspherulite crystallization front had relatively low viscosity and $T_{\mathrm{g}}$ (Giordano et al. 2008) due to a high amount of $\mathrm{H}_{2} \mathrm{O}$, pushed out during megaspherulite growth. Close to the crevasses (T10), the T9 domain of MLM is, in places, bent (Fig. 5b). The ductile bending may have been facilitated by the presence of interstitial melt in $\boldsymbol{T} \boldsymbol{9}$ which later transformed to glass and then to quartz, sanidine, or smectite. Formation of the crevasses might have been facilitated by contraction of the crystallized domain, and in case of MLM, by shearing related to the late movement of the lava.

The megaspherulites in the El Viejo lava (Argentina) comprise "growth cones" and "interconal areas" crystallized to lithophysae (Bustos et al. 2020), similar to the OD of ESCM and MLM. However, Bustos et al. (2020) assume a synchronous growth of both domains, where $\mathrm{H}_{2} \mathrm{O}$ was pushed out from the growth cones laterally into the interconal areas.

With MD in EQM, domains of autocycling banding (T9) are laterally juxtaposed with fibrous domains (quartz, feldspar, smectite), with the elongate fibers oriented perpendicular to the EQM outer surface (T14). In places, growth was retarded in T14 causing cone-shaped indentation of the megaspherulite outer surface (T13). Furthermore, some centimeter inside MD, chevronshaped cavities (T15) opened in T14 (Willson et al. 1999). Formation of both $\boldsymbol{T} 13$ and $\boldsymbol{T} 14$ presumably was related to the same cause, a local domain of growth impediment. The domain of growth impediment was surrounded by areas of continuing growth provoking temporal tension at $\boldsymbol{T 1 3}$ and $\boldsymbol{T 1 4}$ leading to the opening of the chevron-shaped cavities.

Common to MD of all three megaspherulites is the formation of centimeter-sized sector-sphere spherulites (T12) on the surface. They nucleated at specific points on the megaspherulite surface such as the outer termination of fractures and $\mathbf{T 1 0}$ crevasses on MLM. These radiate fibrous domains mark the termination of megaspherulite growth (Breitkreuz 2013). 


\section{General aspects of megaspherulite formation-towards a generic model}

Based on the results presented for the three megaspherulite occurrences, which formed in thick rhyolitic lava, the following two questions can be raised:

1. Which physical parameters and which composition of the hosting melt lead to the formation of megaspherulites?

2. How can we explain and generalize the changes of the dominant texture associations from ID to OD and MD?

Figure 1a shows c. 24 SCM megaspherulites distributed across an area of around $1700 \mathrm{~m}^{2}$, i.e., $0.01 / \mathrm{m}^{2}$. This compares with c. $200,000 / \mathrm{m}^{2}$ of millimeter-sized spherulites on an obsidian sample from Roche Rosse, Lipari (collection by C.B.), and it results in a difference in areal number density on the order of $10^{6}$. All three investigated megaspherulites formed in phenocryst-poor lava, where the scarcity of phenocrysts contributed to a low nucleation density. Furthermore, sanidine is a dominant component in the three studied megaspherulites (Table 3). Swanson (1977) carried out experiments on granitoid systems reporting that under low undercooling, K-feldspar has high growth rates but reduced nucleation density. This would also explain the scarcity of small spherulites in the studied megaspherulite sites.

Outcrop analysis and drilling have revealed that some thick obsidian flows contain a crystallized lithoidal core (Manley and Fink 1987). As documented above, this spatial relation (obsidian with megaspherulites overlain by lithoidal rhyolite) holds true for all three lava complexes studied here. Bustos et al. (2020) sketched a similar scenario for the El Viejo megaspherulites in Argentina. The crystallizing domain produces latent heat buffering cooling rate "close to zero" (Huber et al. 2009). Thus, until the lithoidal rhyolite in the lava core has crystallized completely, heat release from the megaspherulite zone towards the top of the lava was impeded, thereby reducing the cooling rate and thus the effective undercooling of the megaspherulite-forming domain. Low cooling rates result in lower $T_{\mathrm{g}}$ (Stevenson et al. 1995; Gottsmann et al. 2002) allowing for a prolonged time span of megaspherulite growth.

From experiments with natural rhyolite, Lofgren (1971a) calculated a growth rate of $10-100 \mu \mathrm{m}$ per day for spherulites. Applying those rates to the investigated occurrences, the growth of a megaspherulite of $4 \mathrm{~m}$ in size would require $\sim 55$ to 550 years. The lower figure is in agreement with data of Smith et al. (2001) who estimated 66 years were needed to grow a 4.3-m SCM. Bustos et al. (2020) also assumed a growth time of c. 55 years for the formation of a 4-m megaspherulite in the El Viejo coulée in northwestern Argentina. Evidence for crystallization of the investigated megaspherulites from a melt above $T_{\mathrm{g}}$ is provided by the presence of (then melt-filled) crevasses (T10) cutting through OD and MD in SCM and MLM. The duration of megaspherulite growth in a rhyolitic melt, and accordingly its size, depends on the dwell time of the hosting melt in a favorable temperature range from c. 850 ${ }^{\circ} \mathrm{C}$ (Stevenson et al. 2001) to c. $730{ }^{\circ} \mathrm{C}\left(T_{\mathrm{g}}\right.$; Giordano et al. 2008). Stevenson et al. (2001) modeled the cooling history of the 90-m-thick Ben Lomond lava flow in New Zealand, showing that it took 50 years for the inner part to cool from 850 to $500{ }^{\circ} \mathrm{C}$. Following these assumptions, the time span for megaspherulite growth might even be less than 50-60 years.

In contrast to SCM, growth of MLM and EQM apparently started with the formation of a central cavity $(\boldsymbol{T} 2)$. Breitkreuz (2013) showed that during lithophysa evolution, the formation of a central cavity is often preceded by initial spherulite growth. However, its visibility depends on the cut or natural breakup. Thus, for MLM and EQM, we cannot exclude the presence of (an) initial spherulite(s). Compared to SCM, MLM and EQM hosts have a higher content of framework builders $\left(\mathrm{SiO}_{2}, \mathrm{Al}_{2} \mathrm{O}_{3} ;\right.$ Fig. 7c). Thus, compared with $\mathrm{SCM}$, MLM and EQM melts had a relatively high viscosity (Giordano et al. 2008), a lower thermal diffusivity (Eriksson et al. 2003), and longer relaxation times (Dingwell and Webb 1990; Breitkreuz 2013) facilitating the formation of cavities. The cavities might also have been formed by shearing inside the emplacing lava during early ID formation. Gonnermann and Manga (2003) numerically modeled that a low strain rate is sufficient to fragment high-viscosity melts.

The abrupt change in dominant textures from T4 (spherulitic growth) in ID to $\boldsymbol{T 9}$ (autocyclic banding) in OD and MD is an important feature of the studied megaspherulites, except for SCM, which developed dendritic growth in ID and OD. But OD of SCM also displays autocyclic banding, in places. Considering the abundance of sanidine and $\mathrm{SiO}_{2}$ modifications in the investigated samples (Table 3), diffusion rates of $\mathrm{K}_{2} \mathrm{O}$ and $\mathrm{SiO}_{2}$ largely controlled megaspherulite growth. Zhang et al. (2010) plotted the binary diffusivity for potassium vs. temperature showing that cooling from 850 to $730{ }^{\circ} \mathrm{C}$ correlates with a decrease in diffusivity $(D)$ from c. -25.5 to $-27.0 \ln D_{\mathrm{K}}\left(D\right.$ in $\left.\mathrm{m}^{2} / \mathrm{s}\right)$. Thus, ID formation, controlled by crystal growth under low supercooling, took much less time compared to OD growth, largely controlled by low diffusivity.

As stated above, silicic lava typically effuses with very low $\mathrm{H}_{2} \mathrm{O}$ content ( $\leq 0.5 \mathrm{wt} \%$; DeGroat-Nelson et al. 1999). Directly in contact with the crystallization front, the hosting melt will have enhanced amounts of $\mathrm{H}_{2} \mathrm{O}$, excluded by the growing megaspherulite, increasing diffusion and nucleation. At low temperatures, the $\mathrm{H}_{2} \mathrm{O}$ could have contributed to the formation of the mordenite-smectite rim around SCM (Table 3). However, the volume of $\mathrm{H}_{2} \mathrm{O}$ pushed out during megaspherulite growth is not sufficient to account for the LOI of 2 to $6 \mathrm{wt} \%$ in the pitchstone hosting MLM, EQM, and SCM (Table 2). Both zeolite (mordenite, the most Sirich zeolite) and smectite (montmorillonite) are low- 
temperature alteration products of volcanic rocks if $\mathrm{Ca}$ and $\mathrm{Mg}$ are high and $\mathrm{K}$ is low (Goodwin and Surdam 1967; Störr et al. 1979; Gilg et al. 2002; Mormone and Piochi 2020). Other minerals such as Mn-garnet, fluorite, aluminosilicates, and phosphates can be related to late fluid activities during cooling. Another source for $\mathrm{H}_{2} \mathrm{O}$ could have been the crystallizing lithoidal domain nearby. In addition, external $\mathrm{H}_{2} \mathrm{O}$ reached the lava leading to hydration of glass, and to the formation of smectite, in the pitchstone and in the megaspherulites (Kirchner 1991).

In Fig. 14, the evolution of the 0.7- to 4.3-m-sized SCM, EQM, and MLM and its major textures are sketched schematically. While all three megaspherulites have features in common, such as the subdivision into ID and OD, and T12 in MD, some textures are dominant in one megaspherulite and scarce (e.g., autocyclic banding, T9) or absent in the next. Following the discussion above, we assume that during ID growth, gradual cooling from $\sim 850$ to $750{ }^{\circ} \mathrm{C}$ (with a cooling rate buffered by the crystallization of the lithoidal zones) allowed for high diffusion rates and thus for high growth rates. During OD formation, and in particular towards termination of megaspherulite growth, a slightly faster cooling from $\sim 750$ to $730{ }^{\circ} \mathrm{C}$ took place and diffusion rates dropped. According to published growth rates reported above, ID and OD formation lasted for a few decades (30-40 years?). With EQM and MLM, cavity formation took place early in ID growth controlled by transient tension or shearing. Spherulites and dendritic domains dominated ID growth. For SCM, the latter continued into OD growth, accentuated by brecciation (T11), presumably caused by transient fluid overpressure. OD and MD accretion took place under decreasing temperatures and diffusion rates when autocyclic banding (T9) became dominant with EQM and MLM. Cooling down to $T_{\mathrm{g}}$ terminated megaspherulite growth; but shortly before this point, fibrous crystals with a lot of interstitial melt (later transformed to smectite; T14) grew, chevronshaped cavities opened (T15), and half-spherulites grew, as scattered over the outer skin of the megaspherulite. SCM and MLM then formed radiate to curved crevasses (T10) caused presumably by shrinking or simple shear.

\section{Conclusions}

Megaspherulites from Silver Cliff (USA), El Quevar (Argentina), and Meissen (Germany) were investigated by polarizing microscopy, cathodoluminescence microscopy and spectroscopy, and scanning electron microscopy, as well as X-ray diffraction and X-ray fluorescence to obtain detailed information concerning their characteristic textures and whole-rock chemical as well as mineral compositions. The study aimed to constrain the origin of the megaspherulites and the specific physicochemical conditions for megaspherulite crystallization. Based on the macro- and microscopic texture and composition data of the three megaspherulite occurrences presented here, the following conclusions can be drawn:

- Megaspherulite crystallization occurs only in rhyolitic melts (similar in chemical composition to all investigated samples here).

- A favorable place to grow megaspherulites in a highvolume lava is a location close to a large mass of crystallizing lithoidal rhyolite; the emanating latent heat may keep a low supercooling long enough to start megaspherulite growth; megaspherulite growth retards and terminates due to cooling and decreasing diffusion rates.

- Megaspherulite growth starts and ends in melt above $T_{\mathrm{g}}$ as revealed by the presence of crevasses filled with melt, crosscutting the outer domains.

- During advancing megaspherulite growth, an increasing amount of interstitial melt and porosity forms between the microcrystals, replaced/filled later by secondary smectite.

- Secondary alteration by fluids may change the composition and texture of the megaspherulites and result in the formation of smectite and zeolite as well as other minerals such as garnet, fluorite, aluminosilicates, or phosphates.

The commonalty of these processes at the three different locations suggests that this could be a global model common to megaspherulite generation in any thick, cooling rhyolitic unit.

Supplementary Information The online version contains supplementary material available at https://doi.org/10.1007/s00445-021-01434-7.

Acknowledgments We like to thank Bernhard Schulz (TU Bergakademie Freiberg) for his support with SEM/EDX analyses, Reinhard Kleeberg (TU Bergakademie Freiberg) for assistance with XRD data acquisition, and Robert Möckel (HIF Freiberg) for his help during XRF analyses. Furthermore, we are grateful to Gudrun Geyer and Ronny Ziesemann for preparation of samples and polished thin sections. We highly acknowledge comprehensive reviews by Ben Andrews and Jonathan Castro and careful editing by Katharine Cashman and Andrew Harris.

Funding Open Access funding enabled and organized by Projekt DEAL.

Open Access This article is licensed under a Creative Commons Attribution 4.0 International License, which permits use, sharing, adaptation, distribution and reproduction in any medium or format, as long as you give appropriate credit to the original author(s) and the source, provide a link to the Creative Commons licence, and indicate if changes were made. The images or other third party material in this article are included in the article's Creative Commons licence, unless indicated otherwise in a credit line to the material. If material is not included in the article's Creative Commons licence and your intended use is not permitted by statutory regulation or exceeds the permitted use, you will need to obtain permission directly from the copyright holder. To view a copy of this licence, visit http://creativecommons.org/licenses/by/4.0/. 


\section{References}

Allégre CJ, Provost A, Jaupart C (1981) Oscillatory zoning: a pathological case of crystal growth. Nature 294:223-228

Baxter PJ, Bonadonna C, Dupree R, Hards VL, Kohn SC, Murphy MD, Nichols A, Norton G, Searl A, Sparks RSJ, Vickers BP (1999) Cristobalite in volcanic ash of the Soufriere Hills Volcano, Montserrat, British West Indies. Science 283(5405):1142-1145

Breitkreuz C (2013) Spherulites and lithophysae - 200 years of investigation on high-temperature crystallization domains in silica-rich volcanic rocks. Bull Volcanol 75:705-720

Bryan WH (1941) Spherulites and allied structures, part 1. Proc Roy Soc Queensl Austral 65:51-69

Bustos E, Báez WA, Bardelli L, McPhie J, Sola A, Chiodi A, Simón V, Arnosio M (2020) Genesis of megaspherulites in El Viejo Rhyolitic Coulee (Pleistocene), Southern Puna, Argentina. Bull Volcanol 82: $1-16$

Cas RAF, Wright JV (1987) Volcanic successions - modern and ancient. Unwin Hyman, London 527 pp

Castro JM, Beck P, Tuffen H, Nichols ARL, Dingwell DB, Martin MC (2008) Timescales of spherulite crystallization in obsidian inferred from water concentration profiles. Amer Min 93:1816-1822

Clay PL, O’Driscoll B, Gertisser R, Busemann H, Sherlock SC, Kelly SP (2013) Textural characterization, major and volatile element quantification and Ar-Ar systematics of spherulites in the Rocche Rosse obsidian flow, Lipari, Aeolian Islands: a temperature continuum growth model. Contrib Mineral Petrol 165:373-395

Cross CW (1891) Constitution and origin of spherulites in acid eruptive rocks. Bull Philos Soc Wash 11:411-443

DeGroat-Nelson PJ, Cameron BI, Fink JH, Holloway JR (1999) Hydrogen isotope analysis of rehydrated silicic lavas: implications for eruption mechanisms. Earth Planet Sci Lett 185:331-341

Dingwell DB, Webb SL (1990) Relaxation in silicate melts. Eur J Mineral 2:427-449

Eriksson R, Hayashi M, Seetharaman S (2003) Thermal diffusivity measurements of liquid silicate melts. Int J Thermophys 24:785-797

Fink JH (1983) Structure and emplacement of a rhyolitic obsidian flow: Little Glass Mountain, Medicine Highland, northern California. Geol Soc Am Bull 94:362-380

Gilg HA, Weber B, Kasbohm J, Frei R (2002) Isotope geochemistry and origin of illite-smectite and kaolinite from the Seilitz and Kemmlitz kaolin deposits, Saxony, Germany. Clay Miner 38:95-112

Giordano D, Russell JK, Dingwell DB (2008) Viscosity of magmatic liquids: a model. Earth Planet Sci Lett 271:123-134

Gonnermann HM, Manga M (2003) Explosive volcanism may not be an inevitable consequence of magma fragmentation. Nature 426(6965): 432-435

Goodwin JH, Surdam RC (1967) Zeolitization of Tuffaceous rocks of the Green River Formation, Wyoming. Science 157(3786):307-308

Gottsmann J, Giordano D, Dingwell DB (2002) Predicting shear viscosity during volcanic processes at the glass transition: a calorimetric calibration. Earth Planet Sci Lett 198:417-427

Götze J (2012) Application of cathodoluminescence (CL) microscopy and spectroscopy in geosciences. Microsc Microanal 18:1270-1284

Götze J, Hofmann B, Machałowski T, Tsurkan MV, Jesionowski T, Ehrlich H, Kleeberg R, Ottens B (2020) Biosignatures in subsurface filamentous fabrics (SFF) from the Deccan Volcanic Province, India. Minerals 10:540

Hoffmann U, Breitkreuz C, Breiter K, Sergeev S, Stanek K, Tichomirova M (2013) Carboniferous-Permian volcanic evolution in Central Europe $-\mathrm{U} / \mathrm{Pb}$ ages of volcanic rocks in Saxony (Germany) and Northern Bohemia (Czech Republic). Int J Earth Sci 102:73-99

Holten T, Jamtveit B, Meakin P (2000) Noise and oscillatory zoning of minerals. Geochim Cosmochim Acta 64:1893-1904
Holzhey G (1994) Zur Ausbildung der Randfazies rhyolitischer Rotliegend Vulkanite des Thüringer Waldes. Geowiss Mitt Thüring 2:45-71

Horwell CJ, Williamson BJ, Llewellin EW, Damby DE, Le Blond JS (2013) The nature and formation of cristobalite at the Soufrière Hills volcano, Montserrat: implications for the petrology and stability of silicic lava domes. Bull Volcanol 75:696

Huber C, Bachmann O, Dufek J (2009) The limitations of melting on the reactivation of silicic mushes. J Volcanol Geotherm Res 195:97-105

Iddings JP (1885a) On the occurrence of fayalite in the lithophyses of obsidian and rhyolite in the Yellowstone National Park. Amer J Sci $30: 175-180$

Iddings JP (1885b) Obsidian Cliff, Yellowstone National Park. USGS, Seventh Ann Rep 1888:253-295

Iddings JP (1887) The nature and origin of lithophysae and the lamination of acid lavas. Amer J Sci 33:36-45

Iddings JP (1891) Spherulitic crystallization. Bull Philos Soc Wash 11: 445-464

Jentsch F (1981) Zur Minerogenie glasiger Subsequenzvulkanite im sächsischen Raum. Freiberg Forsch Hefte C361:1-57

Keith HD, Padden FJ (1963) A phenomenological theory of spherulitic crystallization. J Appl Phys 34:2409-2421

Kirchner JG (1991) Mordenite and montmorillonite alteration of glass structures in a rhyolite pipe, Northern Black Hills, South Dakota. Mountain Geol 28(4):23-30

Kobayashi R (1993) Modeling and numerical simulations of dendritic crystal growth. Phys D: Non-linear Phenom 63(3-4):410-423

Krbetschek MR, Götze J, Irmer G, Rieser U, Trautmann T (2002) The red luminescence emission of feldspar and its wavelength dependence on $\mathrm{K}, \mathrm{Na}, \mathrm{Ca}$ - composition. Mineral Petrol 76:167-177

Lange JM, Heide K (1996) Pitchstone, rhyolite and kaolin near Meißen, Saxony. Chem Erde 56:511-521

Laurenzi MA, Balestrieri ML, Bigazzi G, Neto JCH, Junes PJ, Norelli P, Oddone M, Araya AMO, Viramonte JG (2007) New constraints on ages of glasses proposed as reference materials for fission-track dating. Geostand Geoanal Res 31:105-124

Le Bas MJ, Le Maitre RW, Streckeisen A, Zanettin B (1986) A chemical classification of volcanic rocks based on the total alkali-silica diagram. J Petrol 27:745-750

Liesegang RE (1913) Überschalig-disperse Systeme. Kolloid-Zeitschr 12:269-273

Lofgren GE (1971a) Spherulitic textures in glassy and crystalline rocks. J Geophys Res 76:5635-5648

Lofgren GE (1971b) Experimentally produced devitrification textures in natural rhyolitic glass. Geol Soc Am Bull 82:111-124

Manley CR, Fink JH (1987) Internal textures of rhyolite flows as revealed by research drilling. Geology 15:549-552

McArthur AN, Cas RA, Orton GJ (1998) Distribution and significance of crystalline, perlitic and vesicular textures in the Ordovician Garth Tuff (Wales). Bull Volcanol 60:260-285

Mormone A, Piochi M (2020) Mineralogy, geochemistry and genesis of zeolites in Cenozoic pyroclastic flows from the Asuni area (Central Sardinia, Italy). Minerals 10:268

Neuser RD, Bruhn F, Götze J, Habermann D, Richter DK (1995) Kathodolumineszenz: Methodik und Anwendung. Zentralbl Geol Paläont I, H 1/2:287-306

Ottens B, Götze J (2016) Achatwelt China. extraLapis Nr. 51. Christian Weise Verlag GmbH, München

Perrotta AJ, Grubbs DK, Martin ES, Dando NR, McKinstry HA, ChiZawrah MF, Hamzawy EMA (1989) Chemical Stabilization of betaCristobalite. J Amer Ceram Soc 72:441-447

Richthofen FV (1860) Geognostische Beschreibung der Umgebung von Predazzo, Sanct Cassian und der Seisser Alpe in Süd Tyrol. Justus Perthes Verlag, Gotha, pp 1-32

Rose G (1827) Über den sogenannten krystallisierten Obsidian. Poggendorff Ann Phys Chem 10:323-326 
Sakka S, MacKenzie JD (1971) Relationship between apparent glass transition temperature and liquidus temperature for inorganic glasses. J Non-Cryst Sol 6:145-162

Siems PL (1968) Volcanic geology of the Rosita Hills and Silver Cliff district, Custer County, Colorado. Col School Mines Q 63:89-124

Smith RK, Tremallo RL, Lofgren GE (2001) Growth of megaspherulites in a rhyolitic vitrophyre. Amer Min 86:589-600

Stevens-Kalceff MA (2009) Cathodoluminescence microcharacterization of point defects in $\alpha$-quartz. Min Mag 73:585-606

Stevenson RJ, Dingwell DB, Webb SL, Bagdassarov NS (1995) The equivalence of enthalpy and shear stress relaxation in rhyolitic obsidians and quantification of the liquid-glass transition in volcanic processes. J Volcanol Geotherm Res 68:297-306

Stevenson RJ, Dingwell DB, Bagdassarov NS, Manley CR (2001) Measurement and implication of "effective" viscosity for rhyolite flow emplacement. Bull Volcanol 63:227-237

Stirling M (1969) Solving the mystery of Mexico's Great Stone spheres. Natl Geogr 136(2):294-300
Störr M, Ha NT, Zwahr H (1979) Vorkommen von Zeolithen (Klinoptilolith und Mordenit) in natürlichen Umwandlungsprodukten des Pechsteins von Garsebach bei Meißen. Z Geol Wiss 7:1455-1456

Swanson SE (1977) Relation of nucleation and crystal-growth rate to the development of granitic textures. Amer Min 62:966-978

Taut T, Kleeberg R, Bergmann J (1998) Seifert software: the new Seifert Rietveld program BGMN and its application to quantitative phase analysis. Mat Struct 5:57-66

Trivedi R, Kurz W (1994) Dendritic growth. Intern Mat Rev 39:49-74

Watkins J, Manga M, Huber C, Martin M (2009) Diffusion-controlled spherulite growth in obsidian inferred from $\mathrm{H}_{2} \mathrm{O}$ concentration profiles. Contrib Mineral Petrol 157:163-172

Willson JJ, Goddard P, Couch S, Viramonte JG (1999) Characterisation of the Quiron rhyolite El Quevar volcanic complex, Salta. 14th Congr Geol Argent Salta Actas 14:222-224

Zawrah MF, Hamzawy EMA (2002) Effect of cristobalite formation on sinterability, microstructure and properties of glass/ceramic composites. Ceram Int 28:123-130

Zhang Y, Ni H, Chen Y (2010) Diffusion data in silicate melts. Rev Mineral Geochem 72:311-408 